\title{
Key drivers influencing the colonization of periphytic ciliates and their functional role in hydrologically dynamic floodplain lake ecosystem
}

\author{
Barbara Vlaičević $^{1, *}$ (D), Renata Matoničkin Kepčija ${ }^{2}$ (1), Vesna Gulin ${ }^{2}$, Ivana Turković Čakalić ${ }^{1}$, \\ Mirjana Kepec ${ }^{3}$ and Dubravka Čerba ${ }^{1}$ \\ ${ }^{1}$ Department of Biology, Josip Juraj Strossmayer University of Osijek, Cara Hadrijana 8/A, 31000 Osijek, Croatia \\ ${ }^{2}$ Department of Biology, Faculty of Science, University of Zagreb, Rooseveltov trg 6, 10000 Zagreb, Croatia \\ ${ }^{3}$ Vocational School Đurđevac, Dr. Ivana Kranjčeva 5, 48350 Đurđevac, Croatia
}

Received: 15 June 2021 / Accepted: 12 August 2021

\begin{abstract}
We investigated the colonization process and community dynamics of periphytic ciliates in a floodplain lake. To elucidate the functional role of ciliates, we investigated variations in their functional traits during colonization. Our research revealed that ciliate colonization process differs significantly between spring and summer, mainly due to differences in water temperature and hydrological regime. The most pronounced influence of temperature-initiated differences was observed during the initial phase of colonization, during which faster colonization with different pioneer species, and more diverse and abundant ciliate community characterized the summer initial phase. Hydrological changes significantly affected periphytic communities during the intermediate and late phases, resulting in different patterns of the colonization process. Mitigation of suspended food particles during flooding periods led to a decrease in ciliate abundance and the dominance of mobile benthivore ciliates (raptorial and filter feeders), whilst during more stable periods of low water, sessile planktivores (filter feeders) that consume suspended particles, dominated. They are considered to be main representatives of periphytic ciliates in floodplain lakes, playing a significant role in the pelagic-benthic coupling. The results of the present study offer new insights into the ecology and functional role of periphytic ciliates in a floodplain ecosystems of temperate regions.
\end{abstract}

Keywords: Ciliated phagotrophic protists / periphyton / pelagic-benthic coupling / Danube / hydrological regime

\begin{abstract}
Résumé - Facteurs clés influençant la colonisation des ciliés périphytiques et leur rôle fonctionnel dans l'écosystème d'un lac de plaine inondable hydrologiquement dynamique. Nous avons étudié le processus de colonisation et la dynamique des communautés de ciliés périphytiques dans un lac de plaine d'inondation. Pour élucider le rôle fonctionnel des ciliés, nous avons étudié les variations de leurs caractéristiques fonctionnelles pendant la colonisation. Nos recherches ont révélé que le processus de colonisation des ciliés diffère significativement entre le printemps et l'été, principalement en raison des différences de température de l'eau et du régime hydrologique. L'influence la plus prononcée des différences induites par la température a été observée pendant la phase initiale de la colonisation, au cours de laquelle une colonisation plus rapide avec différentes espèces pionnières, et une communauté de ciliés plus diverse et plus abondante ont caractérisé la phase initiale d'été. Les changements hydrologiques ont affecté de manière significative les communautés périphériques pendant les phases intermédiaire et tardive, entraînant des modèles différents du processus de colonisation. La réduction des particules alimentaires en suspension pendant les périodes d'inondation a conduit à une diminution de l'abondance des ciliés et à la dominance des ciliés benthivores mobiles (rapaces et filtreurs), tandis que pendant les périodes plus stables de basses eaux, les planctivores sessiles (filtreurs) qui consomment les particules en suspension, ont dominé. Ils sont considérés comme les principaux représentants des ciliés périphytiques dans les lacs de plaine, jouant un rôle important dans le couplage pélagique-benthique. Les résultats de la présente étude offrent de nouvelles
\end{abstract}

\footnotetext{
*Corresponding author: barbara.vlaicevic@biologija.unios.hr
} 
perspectives sur l'écologie et le rôle fonctionnel des ciliés périphytiques dans les écosystèmes des plaines d'inondation des régions tempérées.

Mots clés : Protistes ciliés phagotrophes / périphyton / couplage pélagique-benthique / Danube / régime hydrologique

\section{Introduction}

In many aquatic ecosystems, surface-associated communities are considered hotspots of microbial diversity, including the diversity of ciliated phagotrophic protists (Arndt et al., 2003; Parry, 2004; Weitere et al., 2018). These communities, termed periphytic or biofilm communities, represent complex and fully functional microecosystems, composed of both autotrophic (cyanobacteria and algae) and heterotrophic (bacteria, fungi, phagotrophic protists and metazoans) organisms embedded in a matrix of extracellular polymeric substances (Costerton et al., 1987; Stoodley et al., 2002) and attached to an exposed surface in aquatic environment (Azim et al., 2005; Mora-Gómez et al., 2016; Wu, 2017). Periphyton is recognized as an important biological component of aquatic ecosystems because of its significant role in primary production, nutrient turnover, food webs and organic matter processing, making it an important energy source for higher trophic levels (Azim et al., 2005; Larned, 2010; Wu, 2017).

Ciliated phagotrophic protists generally achieve high diversity and abundance in periphyton, and are found in a wide range of micro-niches due to their diverse feeding and nutritional mechanisms (Arndt et al., 2003; Parry, 2004; Sigee, 2005; Weitere et al., 2018). These microorganisms are involved in trophic interactions within the periphyton, but also with the surrounding water column (Weitere et al., 2003; Ackermann et al., 2011; Früh et al., 2011). Based on the food particles they consume, ciliates are classified into several functional groups such as detritivores, bacterivores, algivores, omnivores, predators and histophages (Pratt and Cairns, 1985; Mieczan, 2005; Zhang et al., 2012). When considering the feeding mechanism, there are raptorial feeders, filter feeders and diffusion feeders (suctorians) (Verni and Gualtieri, 1997; Finlay and Esteban, 1998; Esteban et al., 2015). As one of the main consumers of organic debris and living microorganisms (particularly algae and bacteria), ciliates represent an important link between lower and higher trophic levels in freshwater habitats and can control algal and bacterial populations (Arndt et al., 2003; Parry, 2004; Norf et al., 2009b; Yang et al., 2016).

Previous studies have shown that periphytic communities are often dominated by suspension-feeding or planktivorous ciliates (filter feeders), such as sessile peritrichs, which play a significant role in transferring planktonic production to the periphytic food web and thus contribute to the pelagic-benthic coupling (Früh et al., 2011; Kathol et al., 2011; Weitere et al., 2018). Another important function of periphytic ciliates, especially those species that are attached to the substrate via extracellular structures such as stalks, is to create a threedimensional structure of the periphyton (Arndt et al., 2003). Mobile ciliates that actively forage for surface-associated prey (periphytivores or benthivores) can influence the periphyton architecture by collecting food particles directly from the periphyton mat, thereby influencing the spatial heterogeneity of the periphyton and the population dynamics of other microbiota (Arndt et al., 2003; Böhme et al., 2009; Risse-Buhl and Küsel, 2009). Surface-feeding ciliates can collect food particles from the periphyton either by filtration (filter feeders) or by individually capturing relatively large food particles (e.g. filamentous cyanobacteria, diatoms, dinoflagellates, other phagotrophic protists), often using various food-trapping devices such as cytopharyngeal basket or extrusomes (raptorial feeders).

Clean substrates can be rapidly colonized by different microorganisms (Costerton et al., 1987; Arndt et al., 2003; Vasudevan, 2014). The community structure of periphytic ciliates changes significantly during the colonization process, which can be divided into phases such as initial or early phase, transitional or intermediate phase and equilibrium (late or mature) phase (Früh et al., 2011; Zhang et al., 2012, 2013; Sikder et al., 2019), being consistent with the general predictions of the MacArthur-Wilson model for island colonization (MacArthur and Wilson, 1963; Cairns et al., 1969; Arndt et al., 2003; Zhang et al., 2013; Sikder et al., 2019). In the initial phase of colonization, the high immigration rate of new species leads to a rapid increase in the species number on a new substrate, and the extinction rate of existing species is low. Over time, the immigration rate begins to decrease while the extinction increases, and eventually an equilibrium is reached. At this point the transition from non-interactive species accumulation to interactive biological processes such as competition and predation occurs in the community. The time required for equilibrium to be reached within the community is mainly determined by environmental parameters such as water temperature and trophic conditions, whereby in nutrient-rich environments it may occur in the period of two weeks (Strüder-Kypke, 1999). Once equilibrium is reached, the fluctuations in the species numbers around a mean depend strongly on food availability, predatory pressure and the availability of microsites for the settlement (Harmsworth and Sleigh, 1993; Primc-Habdija et al., 2001; Vlaičević et al., 2017). An equilibrium number of species can be maintained in a relatively stable environment, however some unusual stress can disrupt the stability of the community (Cairns et al., 1969). Multivariate analyses such as cluster analysis or non-metric multidimensional scaling also distinguish different phases during the colonization process (initial, intermediate and equilibrium) (Zhang et al., 2012, 2013; Sikder et al., 2019). The colonization process of periphytic ciliates usually begins after the adherence of organic material on the substrate surface, which stimulates the attachment of bacteria and algae. In general, the first ciliate colonizers or pioneers, characteristic for the initial phase of colonization, are smaller mobile species (e.g. cyrtophorid Chilodonella uncinata and scuticociliates Cinetochilum margaritaceum and Cyclidium glaucoma) that feed primarily on bacteria (Strüder-Kypke, 1999; Wey et al., 2012; Vlaičević et al., 2017). Although these species are mainly benthivores and utilize surface-associated bacteria (Wey et al., 2012), they have high migration potential, thus 
being able to move from periphyton into the plankton at any time and consume planktonic bacteria (Parry, 2004; Wey et al., 2009). Mobility is an important characteristic of the first colonizers as it allows them to contact the substrate and possibly attach (Sigee, 2005). Larger ciliate representatives with a broader food spectrum, especially sessile filter feeders and predators, colonize the substrate during the later phases of community development (Strüder-Kypke, 1999; Früh et al., 2011; Zhang et al., 2012; Vlaičević et al., 2017).

The development and biological composition of periphytic communities is strongly influenced by environmental conditions, including factors such as light intensity, hydrology, water chemistry, macrophytes, planktonic communities and grazing pressure (Arndt et al., 2003; Liboriussen, 2003; Sigee, 2005; Vermaat, 2005). In temperate lakes, climate is another important factor for periphytic communities, and seasonal variations in environmental conditions (especially light and temperature) can lead to differences in the composition of periphytic phagotrophic protists, including composition of ciliate species (Arndt et al., 2003; Früh et al., 2011; Neury-Ormanni et al., 2020; Sikder et al., 2020). An increase in water temperature leads to an acceleration in ciliate growth rate and colonization, but this is also strongly dependent on resource availability (Norf et al., 2007, 2009b; Früh et al., 2011; Villanueva et al., 2011). The functional diversity of periphytic ciliates can change significantly during the colonization process due to food availability in the periphyton and the surrounding water column (Norf et al., 2009b; Früh et al., 2011; Zhang et al., 2012). In complex and highly dynamic ecosystems such as river floodplains, hydrological changes represent one of the most important factors affecting aquatic biocenoses (Junk et al., 1989; Tockner et al., 1999), including periphytic communities (Rodrigues and Bicudo, 2001; Iwaniec et al., 2006; Vidaković et al., 2012), leading to structural and functional community alterations.

Previous studies conducted in the Kopački Rit floodplain show that changes in water level significantly modify planktonic communities (Mihaljević et al., 2010; Galir and Palijan, 2012; Palijan, 2012), as well as periphytic organisms such as bacteria, algae and invertebrates (Palijan, 2010; Mihaljević and Žuna Pfeiffer, 2012; Vidaković et al., 2012). However, there is no data on how these changes affect colonization trends of periphytic ciliates in different seasons. The literature on the colonization dynamics of ciliates and their functional role in natural periphytic communities is still sparse, especially in temperate floodplain ecosystems. Therefore, the colonization process of periphytic ciliate community in a floodplain lake was studied using the glass slide method (Primc-Habdija et al., 2001, 2005; Gong et al., 2005) during two different seasons, spring and summer. Artificial substrates such as glass slides are particularly suitable for studying the colonization process of periphytic organisms, because the exposure time can be controlled and thus the stages of community development can be analyzed from time zero (Moschini-Carlos et al., 2000).

The main objectives of this study were to indicate which environmental factors mostly affect ciliated phagotrophic protists during periphyton formation on clean substrates and to clarify the ecological importance of periphytic ciliates according to their functional diversity. We also aimed to investigate whether the colonization sequence of periphytic ciliates in both seasons is consistent with the general trend that the first colonizers are mobile bacterivorous species, followed by larger species with more diverse diet and sessile life mode (Strüder-Kypke, 1999; Früh et al., 2011; Zhang et al., 2012; Vlaičević et al., 2017). One of the main objectives was to investigate how changes in the hydrological regime, which are among the most important environmental drivers of periphytic communities in floodplain habitats, influence the colonization process and community structure of periphytic ciliates. We hypothesized that spring and summer flooding, which have become common in the Middle Danube, alter the floodplain environment and consequently the colonization characteristics and structure of the periphytic ciliate community.

\section{Materials and methods}

\subsection{Study site}

The research was conducted in Lake Sakadaš, a floodplain lake located in one of the Danube's largest conserved floodplain areas, Kopački Rit Nature Park (also a Ramsar site, No.: 3HR002) (Fig. 1). This area is located in northeastern Croatia between 1383 and 1410 river km of the Danube and covers an area of about $180 \mathrm{~km}^{2}$. The hydrological regime of the Danube mainly determines the hydrological conditions in the Kopački Rit floodplain and depending on the water level fluctuations of the Danube, two hydrological periods can be distinguished (Palijan and Fuks, 2006; Galir and Palijan, 2012) (Fig. 1). During the low-water period, floodplain water bodies are disconnected from the river channel or some water movement is present, so this phase represents the more stable hydrological phase. The high-water period represents the flood phase, during which the floodplain water bodies are connected to the river and the terrestrial zone is flooded, meaning that hydrological disturbance is present. The flood phase begins when the water level of the Danube rises above $3 \mathrm{~m}$ at the Apatin gauge station (at river $1401.4 \mathrm{~km}$ ) (Tadić and Vidaček, 1999). According to the water level fluctuations of the Danube, several categories of flood events are defined, including minor floods (water level 3.0-3.5 m), moderate floods (water level $3.5-4.0 \mathrm{~m}$ ), major floods (water level 4.0-5.0 m) and extremely high floods (water level exceeding $5.0 \mathrm{~m}$ ). Minor floods inundate about $20 \%$ of the floodplain area, while extremely high floods inundate more than $75 \%$ of the area (Schwarz, 2005; Mihaljević and Stević, 2011) (Fig. 1). Floods are typical in spring and early summer, although they can be expected to occur at any time of the year (Mihaljević et al., 1999). Lake Sakadaš, located in the western part of the floodplain, is connected to the River Danube by the system of channels, which is about $10 \mathrm{~km}$ long. The water surface of the lake is about $0.15 \mathrm{~km}^{2}$, while the average depth is about $5 \mathrm{~m}$, and this lake represents the deepest water depression in the area. In recent decades, the lake has been in a eutrophic and hypertrophic state (Vidaković et al., 2002; Peršić et al., 2010). During the periods of high and prolonged flooding, the growth and spread of macrophyte and metaphyton stands may occur in the Lake Sakadaš (Bogut et al., 2005; Mihaljević et al., 2010; Mihaljević and Stević, 2011). In this study, the sampling station was positioned in a small bay in the eastern part of the lake, close to the lakeshore (Fig. 1). 

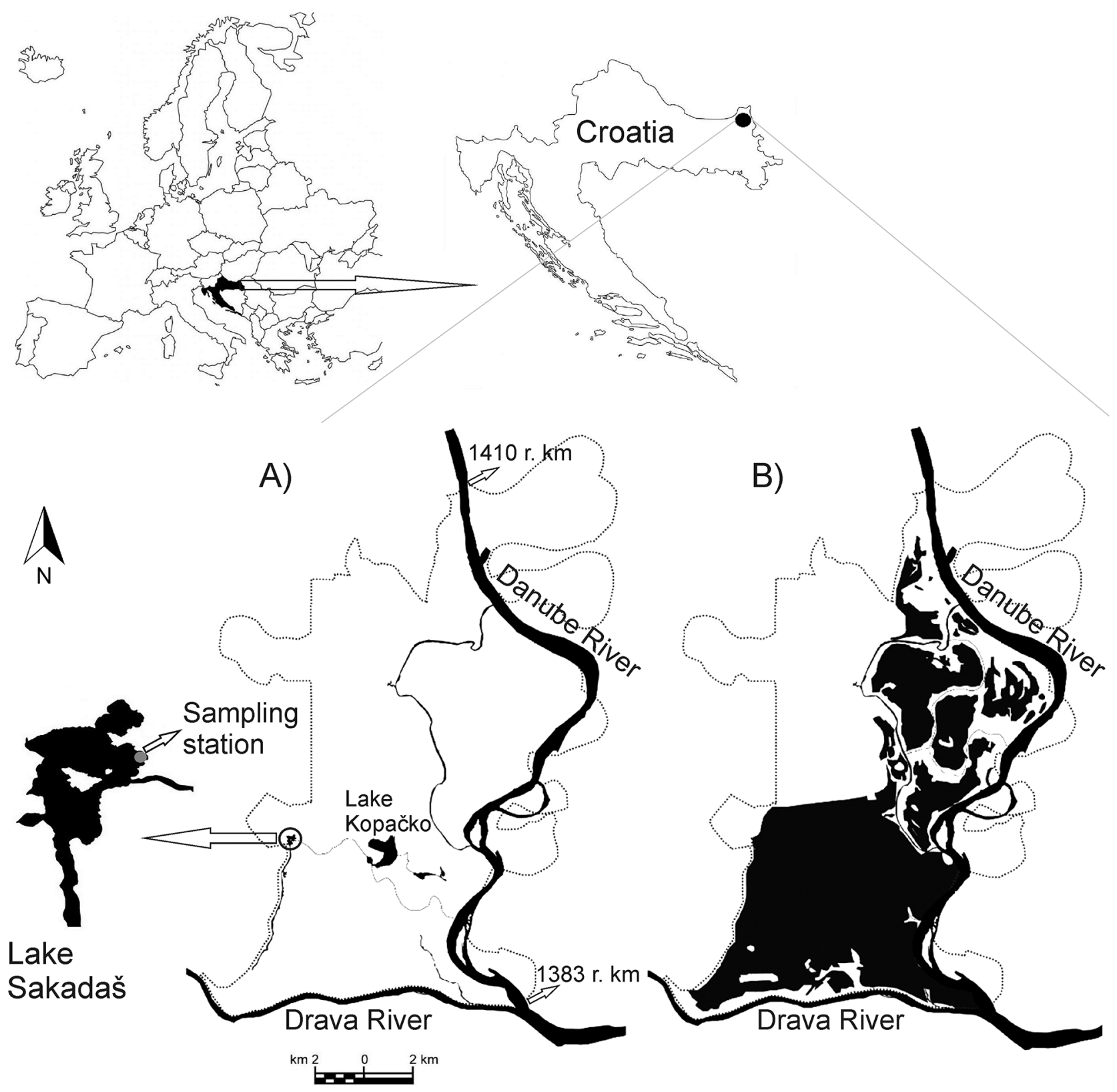

Fig. 1. Map of the Kopački Rit floodplain (floodplain location in the north-east of Croatia is marked with a black dot) during (A) low-water period (Danube water level between 1 and $1.5 \mathrm{~m}$ ) and (B) high-water period (Danube water level around $5 \mathrm{~m}$ ) (maps of the floodplain area are modified from Schwarz (2005) and Mihaljević and Stević (2011)). Dotted line represents the border of the floodplain area. Study area (Lake Sakadaš) is located in the western part of the floodplain. The sampling station in the lake is marked with a grey dot.

\subsection{Experimental design and sampling procedure}

The colonization process of periphytic ciliates was studied in spring and summer of 2010 using glass slides of two different sizes $(7.6 \times 2.6 \mathrm{~cm}$ and $6 \times 14 \mathrm{~cm})$ as artificial substrates for periphyton development. Glass slides arranged in clusters consisting of one smaller and one larger slide were placed in the Lake Sakadaš at a depth of $20 \mathrm{~cm}$ below the water surface and at a distance of $20 \mathrm{~cm}$ using the wooden frame as a slide holder. The frame was placed above the water surface using floating buoys and connected by a rope to stone blocks set on the lake bottom, allowing the frame move freely on the lake surface as the water level fluctuated. The vertically oriented glass slides were therefore submerged at the same depth of $20 \mathrm{~cm}$ throughout the colonization period. The slides with periphyton were randomly sampled after the first day of immersion and at three-day intervals thereafter from April $5^{\text {th }}$ to May $17^{\text {th }}$ during the spring and from July $11^{\text {th }}$ to August $23^{\text {rd }}$ during the summer period. Three replicates (three smaller and three larger glass slides) were collected on each sampling date. Smaller glass slides, used for analysis of the ciliate community, were transported separately to the laboratory in plastic 
containers filled with lake water and stored in a mobile cooler, to keep ciliates alive for the following microscopic analysis. Larger slides, used for the analysis of periphytic biomass and chlorophyll concentrations, were placed separately in the glass bottles containing sterile water. Simultaneously with the collection of the glass slides, water samples (1 1) were collected at a depth of $20 \mathrm{~cm}$ for laboratory analysis of nutrients, chlorophyll $a$ concentration and suspended solids.

\subsection{Environmental parameters}

During each sampling, lake water temperature (WT), dissolved oxygen concentration (DO), $\mathrm{pH}$ and conductivity (COND) were measured in situ using the WTW Multi 340i portable multimeter (Wissenschaftlich-Technische Werkstätten, Weilheim, Germany). Depth of the Lake Sakadaš (D) was measured with a weighted rope, while water transparency (SD) was measured with a Secchi disc. The water level of the Danube (DWL) was registered at the Apatin gauge station at 1401.4 river $\mathrm{km}$. The concentration of nutrients (ammonium $\left(\mathrm{NH}_{4}{ }^{+}\right)$, nitrates $\left(\mathrm{NO}_{3}{ }^{-}\right)$, nitrites $\left(\mathrm{NO}_{2}^{-}\right)$, total nitrogen (TN) and total phosphorus (TP)) in the water was determined by standard analytical methods (APHA, 1985) in the Eco-Laboratory at Vodovod Osijek. As an estimate of phytoplankton abundance, the concentration of chlorophyll $a$ in water (Chl $a \mathrm{~W}$ ) was determined according to Strickland and Parsons (1968) and SCOR-Unesco (1966). Each water sample for Chl $a \mathrm{~W}$ analysis was filtered through a GF/C glass microfiber filter (Whatman International Ltd). The pigments were extracted in $90 \%$ acetone and after $24 \mathrm{~h}$ the sample was centrifuged at 2500-3000 rpm. The absorbance of the supernatant was measured at 630, 645, 663 and $750 \mathrm{~nm}$ wavelengths using a spectrophotometer. The concentration of total suspended solids (TSS), particulate inorganic matter (PIM) and particulate organic matter (POM) in lake water was determined according to Luef et al. (2007). Each water sample was filtered through a pre combusted and weighed GF/C glass microfiber filter (Whatman International Ltd). TSS was determined after filter drying for $24 \mathrm{~h}$ at $105^{\circ} \mathrm{C}$ and PIM was determined after combustion at $450^{\circ} \mathrm{C}$ for $4 \mathrm{~h}$ in a muffle furnace (Nabertherm, LE040K1RN). POM was calculated from the values of TSS and PIM. The trophic state of the Lake Sakadaš during both colonization periods was defined using the values of Carlson's trophic state indices, based on the transparency of the Secchi disc (TSI SD), the concentration of chlorophyll $a$ in water (TSI Chl $a$ ) and total phosphorus (TSI TP) (Carlson and Simpson, 1996).

\subsection{Periphyton analyses}

From each larger glass slide, periphyton was scraped off with razor blade and divided for various analyses. One portion was suspended in $100 \mathrm{ml}$ of tap water and then filtered through a glass microfiber filter for analysis of the concentration of chlorophyll $a(\mathrm{Chl} a \mathrm{P})$ and chlorophyll $c(\mathrm{Chl} c \mathrm{P})$ in periphyton, using the same protocol as for the Chl $a \mathrm{~W}$ analysis. The second portion of the sample was used for periphytic biomass analysis - dry weight (DW), ash weight (AW) and ash-free dry weight (AFDW) (APHA, 1985). Each sample was weighed after drying at $105^{\circ} \mathrm{C}$ for 24 hours and reweighed after combustion at $500^{\circ} \mathrm{C}$ for $1 \mathrm{~h}$ in a muffle furnace.

Olympus BX51 microscope was used for the qualitative and quantitative analysis of the ciliate community and the ciliates were examined at magnifications $100 \times, 200 \times, 400 \times$ and $1000 \times$. At the beginning of the experiment, the periphyton was examined directly from the smaller glass slides collected in the field (without scraping it off the slide), inspecting an area of $9.72 \mathrm{~cm}^{2}$. When the periphyton layer became too dense for direct observation, the periphyton from one side of each smaller glass slide (surface area of $19.76 \mathrm{~cm}^{2}$ ) was scraped with a razor blade into $30 \mathrm{~mL}$ of unfiltered lake water and mixed well. Five $0.05 \mathrm{~mL}$ subsamples were taken from each homogenized suspension and examined under the microscope. Ciliates were identified in vivo and the nuclear staining method (Foissner and Berger, 1996) was also applied for more precise identification. Ciliate taxa were identified according to Foissner et al. (1991, 1992, 1994, 1995), Foissner and Berger (1996) and Kreutz and Foissner (2006), while the taxonomic scheme used was that of Adl et al. (2012).

To clarify the functional role of periphytic ciliates, changes in the composition of ciliate functional groups during the colonization process were reviewed. Based on the food source of each taxa, the trophic structure of ciliates was defined according to Pratt and Cairns (1985), Foissner et al. (1991, 1992, 1994, 1995), Foissner and Berger (1996) and personal observation. Classification of ciliates based on the mechanism of food acquisition was done according to Verni and Gualtieri (1997), Finlay and Esteban (1998) and Esteban et al. (2015). Based on their lifestyle, ciliates were designated as sessile (Peritrichia, Suctoria and Heterotrichea - Stentor species) and mobile (Coppellotti and Matarazzo, 2000). The abundance of ciliates was calculated from three replicate glass slides at each sampling occasion and expressed as the number of individuals per square centimeter (ind. $\mathrm{cm}^{-2}$ ), whereby in the colonial peritrichs individual zooids were counted (Primc-Habdija et al., 2005). Ciliate representatives that reached a relative abundance greater than $5 \%$ on a sampling date during the colonization period (dominant taxa) were considered suitable for describing temporal changes in the community structure during the colonization process.

\subsection{Statistical analysis}

Multivariate analyses of periphytic ciliate communities developed in two different seasons were performed in the PRIMER 6 software (Clarke and Gorley, 2006). Non-metric multidimensional scaling (NMDS) was performed to determine the similarity between ciliate communities during each colonization period separately. Analysis of similarity (ANOSIM) was used to identify the significant differences between ciliate communities of two colonization periods. NMDS and ANOSIM were applied to the Bray-Curtis similarity matrix based on the $\log$-transformed $(\log (x+1))$ ciliate abundance data. The contribution of different ciliate taxa to the average dissimilarity between groups was assessed using the SIMPER analysis. A multivariate ordination method (Redundancy Analysis, RDA) was applied to analyze the relationship between the environmental factors and ciliate abundance using software CANOCO for Windows version 4.5 

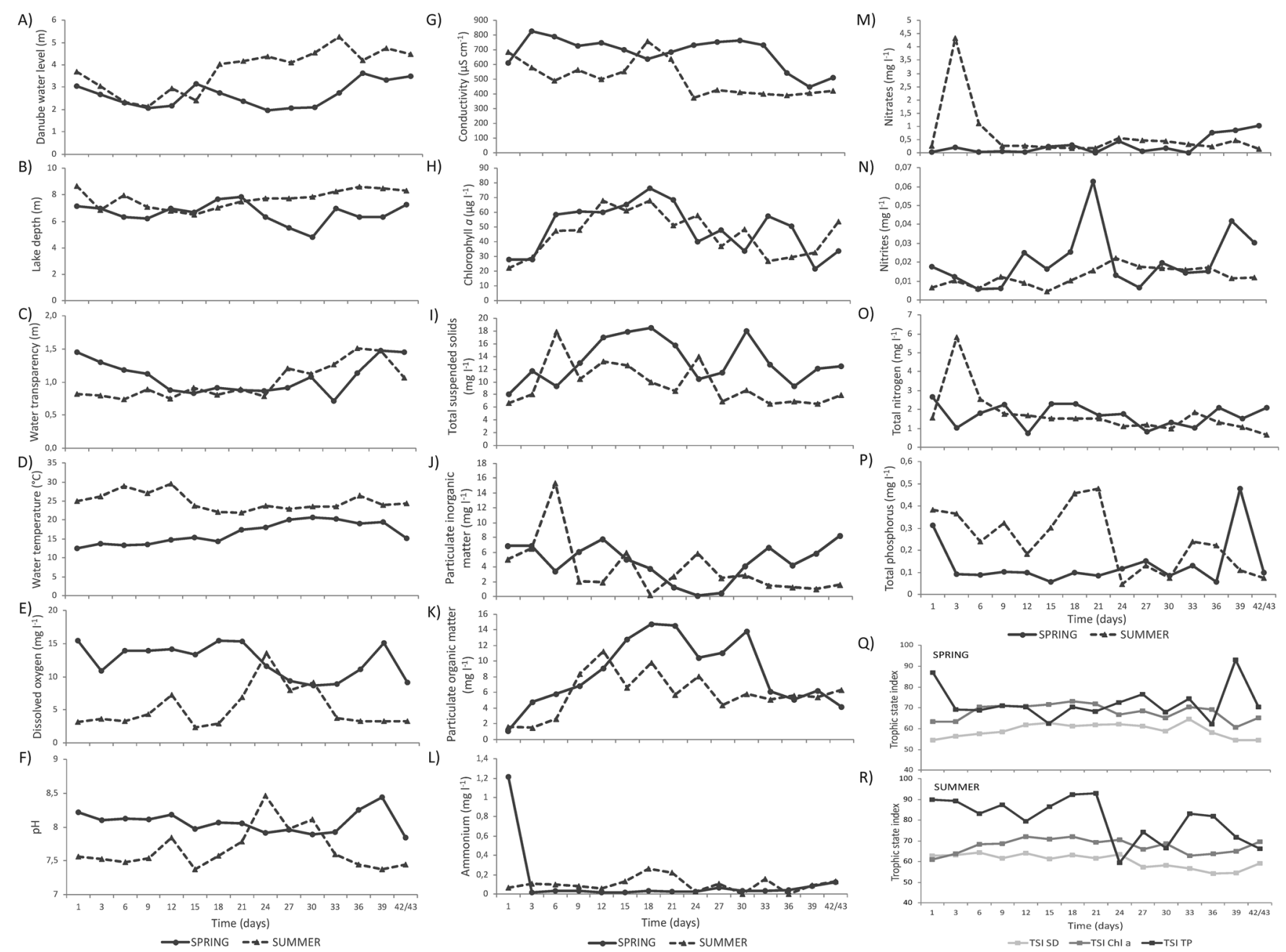

Fig. 2. Abiotic and biotic water parameters $(A-P)$ and trophic state indices $(\mathrm{Q}$ and $\mathrm{R})$ (TSI SD - trophic state index based on Secchi disc transparency, TSI Chl $a$ - trophic state index based on the concentration of chlorophyll $a$ in water and TSI TP - trophic state index based on total phosphorus in water) during the spring (day 1-day 42) and summer (day 1-day 43) colonization period in 2010. Parameters and indices: (A) Danube water level, (B) lake depth, (C) water transparency, (D) water temperature, (E) dissolved oxygen, (F) pH, (G) conductivity, (H) chlorophyll $a$ in water, (I) total suspended solids, (J) particulate inorganic matter, (K) particulate organic matter, (L) ammonium, (M) nitrates, $(\mathrm{N})$ nitrites, $(\mathrm{O})$ total nitrogen, $(\mathrm{P})$ total phosphorus, $(\mathrm{Q})$ trophic state indices during spring colonization period, $(\mathrm{R})$ trophic state indices during summer colonization period. Only $(A)$ refers to the Danube, all the others $(B-R)$ refer to the Lake Sakadaš.

(Ter Braak and Šmilauer, 2002). This analysis was suggested by the initially performed Detrended Correspondence Analysis (DCA), according to which the value of the longest gradient did not exceed 3.0, which made the linear method seem more appropriate (Lepš and Šmilauer, 2003). Ciliate abundance data and environmental variables were log-transformed prior to RDA. A Monte Carlo permutation test with 499 permutations and the manual forward selection option was performed to identify the significant $(p<0.05)$ environmental variables. Only dominant ciliate taxa were included in the analysis. Spearman correlation coefficient $(R \mathrm{~s})$, calculated in Statistica v. 13.4 (Statsoft, Inc.), was used to analyze the relationship between abiotic and biotic parameters.

Species-time data were fitted to the MacArthur-Wilson equilibrium model (MacArthur and Wilson, 1963). Non-linear squares regression was used to estimate the equilibrium species number $\left(S_{\text {eq }}\right)$ and the colonization rate constant $(G)$. To determine the stabilization time of the ciliate community during the colonization process (time required to reach $99 \%$ $\left.S_{\text {eq }}\right)$, the following equation was used: $S_{t}=S_{\text {eq }}\left(1-e^{-\mathrm{Gt}}\right)$, where $S_{t}$ is the species number at time $t, S_{\mathrm{eq}}$ is the estimated equilibrium species number (asymptotic value) and $t$ is the stabilization time.

\section{Results}

\subsection{Environmental conditions}

Oscillations of abiotic and biotic water parameters during the spring and summer colonization period are presented in Figure 2. Both experiments started at the time of decreasing Danube water level and ending of the flood phase. Most of the colonization process in spring occurred in the absence of floods (Danube water level was lower than $3 \mathrm{~m}$; Fig. 2A), however at the end of the experiment in May 2010, from day 36 of 
Table 1. Statistically significant $(p<0.05)$ Spearman correlation coefficients for environmental variables in Lake Sakadaš during the spring and summer colonization period. Abbreviations: DWL - Danube water level, D - lake depth, SD - Secchi depth (water transparency), WT - water temperature, $\mathrm{DO}-$ dissolved oxygen, $\mathrm{COND}-$ conductivity, $\mathrm{NH}_{4}{ }^{+}-$ammonium, $\mathrm{NO}_{3}{ }^{-}-$nitrates, $\mathrm{NO}_{2}{ }^{-}-$nitrites, $\mathrm{TN}-$ total nitrogen, TP - total phosphorus, Chl $a$ - chlorophyll $a$ in water, TSS - total suspended solids, PIM - particulate inorganic matter, POM - particulate organic matter.

\begin{tabular}{|c|c|c|c|c|c|c|c|c|c|c|c|c|c|c|c|}
\hline \multicolumn{16}{|c|}{ SPRING } \\
\hline & $\overline{D W L}$ & $\mathrm{D}$ & $\mathrm{SD}$ & WT & DO & $\mathrm{pH}$ & COND & $\mathrm{NH}_{4}{ }^{+}$ & $\mathrm{NO}_{2}^{-}$ & $\mathrm{TN}$ & Chl $a$ & TSS & PIM & POM & \\
\hline DWL & & & & & & & -0.69 & & & & & & & & \\
\hline D & & & & & & & & & 0.60 & & & & & & \\
\hline SD & & & & & & & & 0.60 & & & -0.64 & & & -0.63 & \\
\hline WT & & & & & -0.57 & & & & & & & & & & \\
\hline DO & & & & -0.57 & & 0.63 & & & & & & & & & \\
\hline $\mathrm{pH}$ & & & & & 0.63 & & & & & & & & & & \\
\hline COND & -0.69 & & & & & & & & -0.63 & -0.57 & & & & & \\
\hline $\mathrm{NH}_{4}^{+}$ & & & 0.60 & & & & & & & & & & & & \\
\hline $\mathrm{NO}_{3}^{-}$ & & & & & & & & & & & & & & & \\
\hline $\mathrm{NO}_{2}^{-}$ & & 0.60 & & & & & -0.63 & & & & & & & & \\
\hline $\mathrm{TN}$ & & & & & & & -0.57 & & & & & & & & \\
\hline \multicolumn{16}{|l|}{ TP } \\
\hline Chl $a$ & & & -0.64 & & & & & & & & & & & 0.58 & \\
\hline TSS & & & & & & & & & & & & & & 0.72 & \\
\hline PIM & & & & & & & & & & & & & & -0.63 & \\
\hline POM & & & -0.63 & & & & & & & & 0.58 & 0.72 & -0.63 & & \\
\hline \multicolumn{16}{|c|}{ SUMMER } \\
\hline & DWL & $\mathrm{D}$ & $\mathrm{SD}$ & DO & $\mathrm{pH}$ & COND & $\mathrm{NH}_{4}^{+}$ & $\mathrm{NO}_{3}^{-}$ & $\mathrm{NO}_{2}^{-}$ & $\mathrm{TN}$ & $\mathrm{TP}$ & Chl $a$ & TSS & PIM & $\overline{\mathrm{POM}}$ \\
\hline$\overline{\mathrm{DWL}}$ & & 0.54 & 0.63 & & & -0.63 & & & 0.60 & -0.60 & -0.52 & & -0.60 & & \\
\hline D & 0.54 & & & & & & & & & & & -0.68 & -0.64 & & \\
\hline SD & 0.63 & & & & & & & & & & & & -0.75 & -0.54 & \\
\hline \multicolumn{16}{|l|}{ WT } \\
\hline DO & & & & & 0.80 & & & & 0.68 & & & & & & \\
\hline $\mathrm{pH}$ & & & & 0.80 & & & & & 0.53 & & & & & & \\
\hline COND & -0.63 & & & & & & & & -0.60 & & 0.84 & & & & \\
\hline $\mathrm{NH}_{4}^{+}$ & & & & & & & & & & & 0.51 & & & & \\
\hline $\mathrm{NO}_{3}^{-}$ & & & & & & & & & & & & & & & -0.52 \\
\hline $\mathrm{NO}_{2}^{-}$ & 0.60 & & & 0.68 & 0.53 & -0.60 & & & & & & & & & \\
\hline TN & -0.60 & & & & & & & & & & 0.65 & & & & \\
\hline TP & -0.52 & & & & & 0.84 & 0.51 & & & 0.65 & & & & & \\
\hline Chl $a$ & & -0.68 & & & & & & & & & & & 0.71 & & 0.84 \\
\hline TSS & -0.60 & -0.64 & -0.75 & & & & & & & & & 0.71 & & & 0.52 \\
\hline PIM & & & -0.54 & & & & & & & & & & & & \\
\hline POM & & & & & & & & -0.52 & & & & 0.84 & 0.52 & & \\
\hline
\end{tabular}

periphyton development, a new flood of minor to moderate intensity occurred. In summer, after the initial decrease of the Danube water level, floods were absent from day 6 to 15 of the periphyton development. A major flood pulse began in late July 2010, from day 18 of colonization, and continued untill the end of the colonization period. During this flooding period, the extremely high flood was recorded on day 33 of the colonization (Fig. 2A).

In both seasons, the fluctuations in depth and water transparency of the Lake Sakadaš followed the changes in Danube water level (Fig. 2A-C), and during the summer period a significant positive correlation was observed between these two parameters and Danube water level (Tab. 1). Water temperature oscillated from 12.5 to $20.8^{\circ} \mathrm{C}$ in spring and from 22 to $29.5^{\circ} \mathrm{C}$ in summer, with a decrease in temperature values during the periods when floodwaters entered the lake (Fig. 2D).
Considerably lower dissolved oxygen concentrations were measured in summer than in spring (Fig. 2E). The $\mathrm{pH}$ values were above 7 in both seasons, indicating alkaline conditions in the Lake Sakadaš (Fig. 2F). Conductivity showed a significant negative correlation with Danube water level in both seasons (Tab. 1), and lower values were recorded during the flooding periods (Fig. 2G). A significant negative correlation between Chl $a$ concentration and water transparency was found in spring, while Chl $a$ showed a significant negative correlation with lake depth in summer (Tab. 1), and in both seasons peak values of Chl $a$ were found during the low-water periods (Fig. 2H). The highest amounts of total suspended solids (TSS) and particulate organic matter (POM) in both seasons were observed during the more stable periods when floods were absent (Fig. 2I and K). TSS was significantly negatively correlated with Danube water level, lake depth and water 
A)

B)

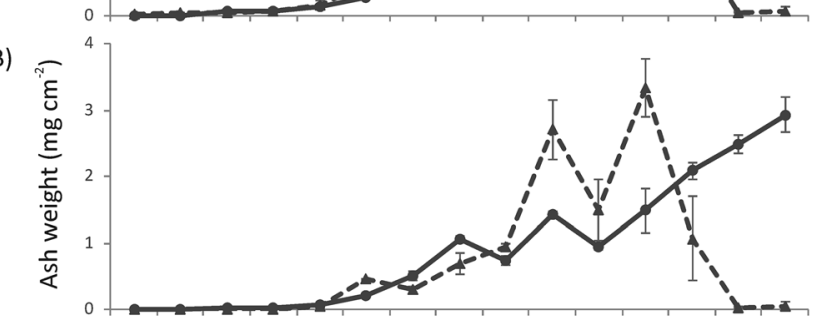

C)

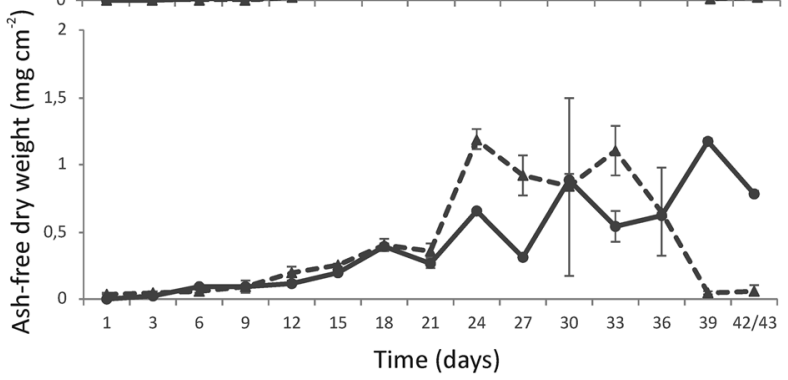

D)

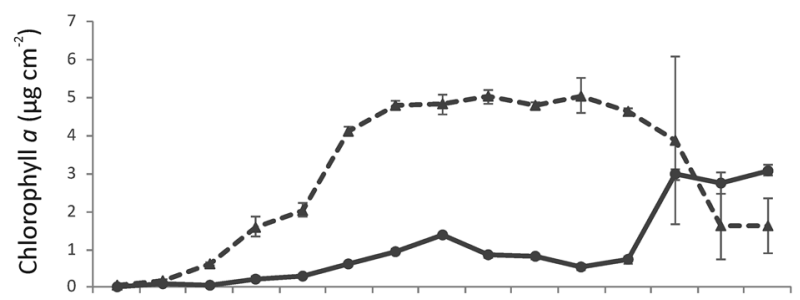

E)

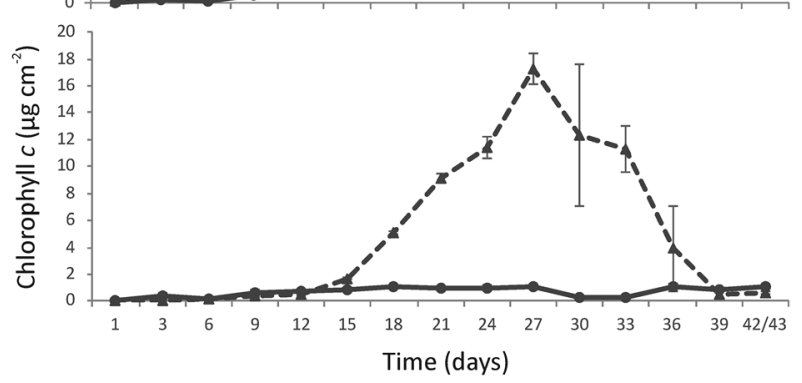

$\rightarrow$ SPRING $\leadsto-$ SUMMER

Fig. 3. Variations in (A, B, C) periphytic biomass and (D, E) chlorophyll concentrations during the spring (day 1-day 42) and summer (day 1-day 43) colonization period in the Lake Sakadaš. Bars represent standard deviations $(n=3)$.

transparency, while it was significantly positively correlated with Chl $a$ concentration in summer. A significant negative correlation between POM and water transparency was observed in spring, and in both seasons POM correlated positively with Chl a concentration (Tab. 1). The highest concentration of particulate inorganic matter was recorded during the low-water period in summer, while in spring it reached the maximum value at the end of colonization study during the high-water period (Fig. 2J). High variation in measured concentrations of nutrients was recorded (Fig. 2L-P). In spring, concentrations of ammonium (exceptional peak at the beginning of the study) and nitrates increased during flooding periods, while the first peak in the concentration of nitrites was recorded during low-water period, and the second one during the flooding period. In summer, flooding periods were characterized by higher concentrations of ammonium, nitrites and nitrates, whereby nitrates exceptionally peaked on the $3^{\text {rd }}$ day of colonization (Fig. 2L-N). High concentrations of total nitrogen and total phosphorus were found in both seasons (Fig. $2 \mathrm{O}$ and $\mathrm{P}$ ). A remarkably high concentration of total nitrogen was recorded on $3^{\text {rd }}$ day of colonization in summer during the flooding period (Fig. 2O). Total phosphorus peaked during the flooding periods in both seasons (Fig. 2P). The results obtained with the trophic state indices confirmed the eutrophic/hypertrophic state of the Lake Sakadaš (Fig. 2Q and R). On day 33 of the summer colonization study, during the period of extremely high flood, metaphyton and submerged (Ceratophyllum demersum) and floating (Salvinia natans and Hydrocharis morsus ranae) macrophytes appeared in the lake and formed dense mats at the sampling location.

\subsection{Periphyton biomass and chlorophyll concentrations}

Changes in periphyton biomass and chlorophyll concentrations differed substantially between the spring and summer seasons, indicating different patterns of periphyton development (Fig. 3). During the spring, both periphyton biomass and chlorophyll concentrations gradually increased over the course of the glass slide exposition, reaching the highest values at the end of the colonization process. Therefore, the accrual phase of periphyton growth was present throughout the entire spring period. In summer, periphyton biomass gradually increased until the first peak was reached on day 27 of colonization period. The highest values were recorded on day 33, after which there was a substantial decrease in periphyton biomass (Fig. 3A-C). Chlorophyll concentrations gradually increased throughout the summer colonization process and the highest values were reached on day $30(\mathrm{Chl} a \mathrm{P})$ and day $27(\mathrm{Chl} c \mathrm{P})$. This phase was followed by a considerable decrease in the values of chlorophyll concentrations, especially after day 33 (Fig. 3D and E). Overall, the summer period was characterized by much higher concentrations of Chl $a \mathrm{P}$ and $\mathrm{Chl} c \mathrm{P}$ in comparison to the spring period. According to the changes in periphyton biomass and chlorophyll concentrations, the shift from the accrual to the loss phase occurred after day 33 of periphyton development in the summer period (Fig. 3). 


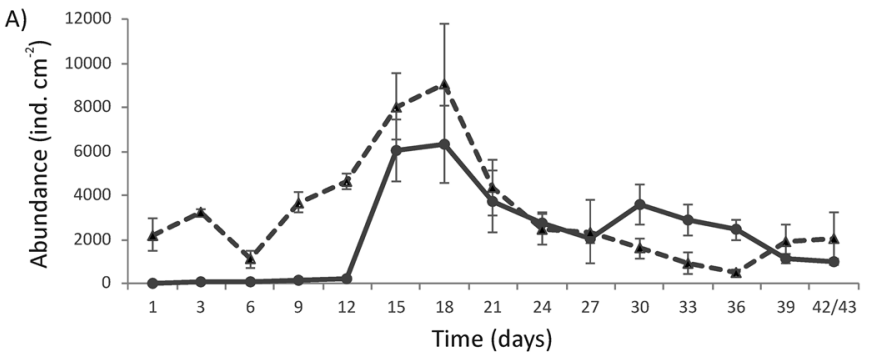

$\rightarrow$ SPRING $\rightarrow-$ SUMMER

C)

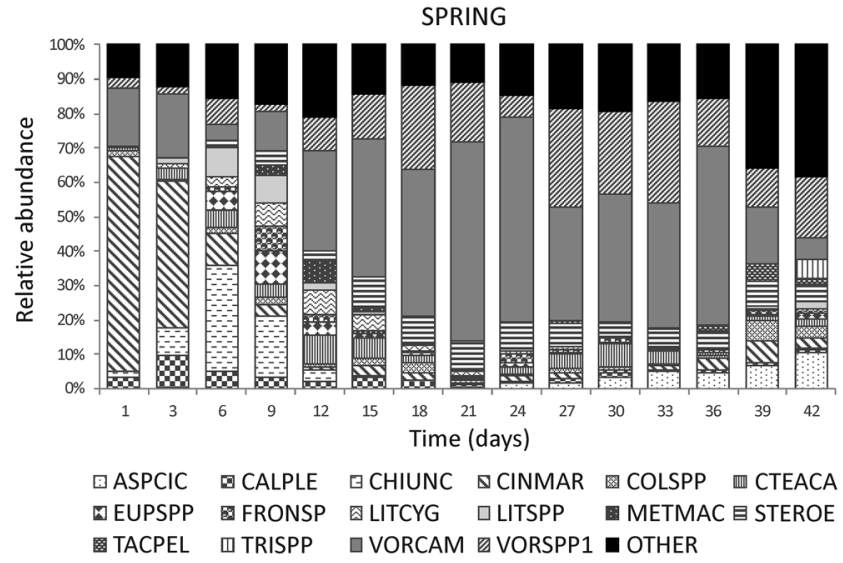

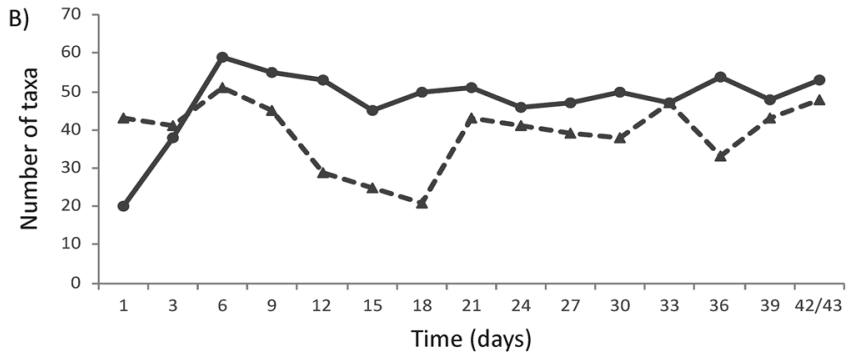

$\because$ SPRING $\leadsto-$ SUMMER

D)

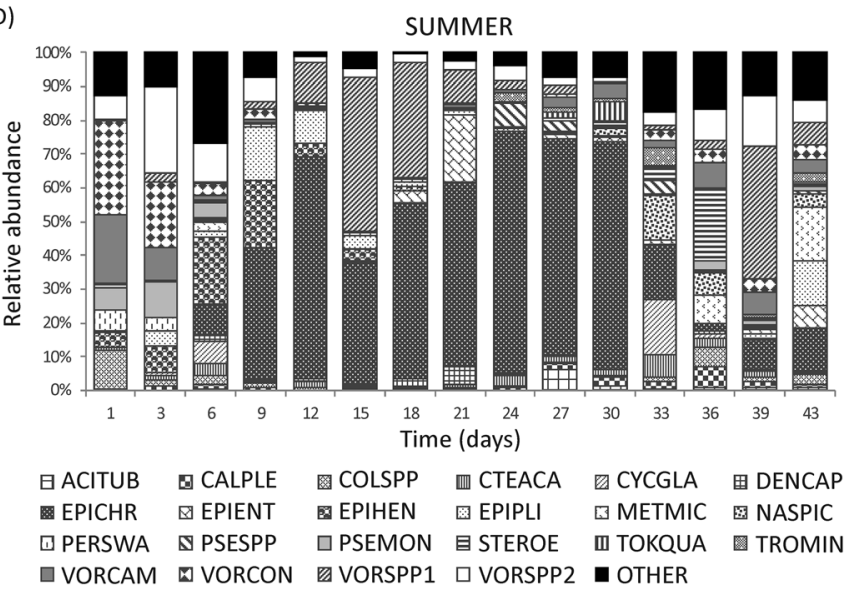

Fig. 4. Variations in (A) total ciliate abundance, (B) number of ciliate taxa and relative abundance of dominant ciliate taxa during (C) spring (day 1-day 42) and (D) summer (day 1-day 43) colonization period in the Lake Sakadaš. Bars represent standard deviations $(\mathrm{n}=3)$. Dominant taxa codes: ACITUB - Acineta tuberosa; ASPCIC - Aspidisca cicada; CALPLE - Calyptotricha pleuronemoides; CHIUNC - Chilodonella uncinata; CINMAR - Cinetochilum margaritaceum; COLSPP - Coleps spp.; CTEACA - Ctedoctema acanthocryptum; CYCGLA Cyclidium glaucoma; DENCAP - Dendrosoma capitata; EPICHR - Epistylis chrysemydis; EPIENT - Epistylis entzii; EPIHEN - Epistylis hentscheli; EPIPLI - Epistylis plicatilis; EUPSPP - Euplotes spp.; FRONSP - Frontonia sp.; LITCYG - Litonotus cygnus; LITSPP Litonotus spp.; METMAC - Metacineta macrocaulis; METMIC - Metacineta micraster; NASPIC - Nassula picta; PERSWA - Peritrichiaswarmer; PSESPP - Pseudochilodonopsis spp.; PSEMON - Pseudovorticella monilata; STEROE - Stentor roeselii; TACPEL - Tachysoma pellionellum; TOKQUA - Tokophrya quadripartita; TRISPP - Trithigmostoma spp.; TROMIN - Trochilia minuta; VORCAM - Vorticella campanula; VORCON - Vorticella convallaria-complex; VORSPP1-Vorticella spp.1 (includes $V$. convallaria-complex and $V$. picta); VORSPP2-Vorticella spp.2 (includes $V$. aquadulcis-complex and V. octava-complex).

\subsection{Periphytic ciliate communities}

\subsubsection{Community structure and colonization dynamics}

During the study, a total of 148 ciliate taxa were recorded, of which 112 taxa were identified during the spring colonization period and 111 taxa during the summer colonization period. Among them, 16 ciliate taxa were determined to be dominant in the community during spring, while 22 taxa were dominant during the summer colonization period (Fig. 4C and D). The number of ciliates in the spring period varied from 20 taxa on the first day of colonization to 59 taxa on day 6 (Fig. 4B), with Peritrichia (the most abundant Vorticella campanula, $V$. convallaria-complex and $V$. picta) and Haptoria (the most abundant Litonotus cygnus and Litonotus spp.) (Fig. 4C) representing the most diverse ciliate groups. During the summer period, the lowest number of taxa (21 taxa) was found on day 18 , while the highest number (51 taxa) was recorded on day 6 (Fig. 4B). This period was characterized by the highest diversity of Peritrichia, represented mainly by species Epistylis chrysemydis, E. entzii, E. hentscheli, E. plicatilis, Pseudovorticella monilata,
Vorticella aquadulcis-complex, V. campanula, $V$. convallariacomplex, $V$. octava-complex and $V$. picta (Fig. 4D).

The MacArthur-Wilson equilibrium model indicated faster ciliate colonization under summer conditions (Fig. 5), when the equilibrium was already established on the first day of periphyton development $\left(S_{\mathrm{eq}}=39.13, G=27.03, t=0.17\right.$, $R=0.76)$. Under spring conditions, ciliates colonized the glass slides more slowly, although a stable community was established by day $8\left(S_{\mathrm{eq}}=50.52, G=0.55, t=8.37\right.$, $R=0.96$ ).

The abundance of periphytic ciliates varied considerably in both seasons, with higher values recorded in the summer (Fig. 4A). In the spring, ciliate abundance increased from an initial 8.81 ind $\mathrm{cm}^{-2}$ to a maximum of 6331.88 ind. $\mathrm{cm}^{-2}$ registered on day 18 . Afterwards, abundance gradually decreased towards the end of the colonization period, with the exception of day 30 . The total ciliate abundance, to which peritrichs contributed the most (contribution of $66 \%$ for the overall spring period), showed a significant positive correlation with particulate organic matter, total suspended solids, water temperature, periphytic chlorophyll $a$ concentration and 
organic matter in periphyton, while it was significantly negatively correlated with water transparency (Tab. 2).

During summer, a high value of ciliate abundance was recorded after only 24 hours of substrate exposition (2212.52 ind $\mathrm{cm}^{-2}$ ), and abundance continued to increase untill day 3 . A decrease was recorded on day 6 , followed by a further increase to a peak value of 9040.37 ind $\mathrm{cm}^{-2}$ on day 18 after which a substantial decrease of the abundance was observed, with the lowest value (487.85 ind $\mathrm{cm}^{-2}$ ) found on day 36 . On day 39 , the abundance began to increase again (Fig. 4A). Total ciliate abundance, to which peritrichs contributed the most (contribution of $86 \%$ for the overall summer period), showed a

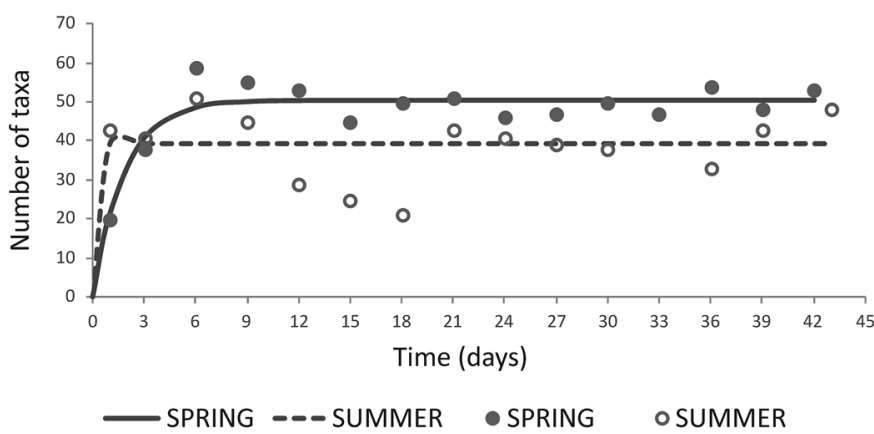

Fig. 5. Colonization curves of periphytic ciliates fitted to the MacArthur-Wilson equilibrium model during the spring (day 1day 42) and summer (day 1-day 43) colonization period in the Lake Sakadaš. Total number of ciliate taxa throughout the colonization periods is represented by solid (spring colonization period) and open circles (summer colonization period) significant negative correlation with lake depth and Danube water level, while it was significantly positively correlated with the concentration of chlorophyll $a$ in water, conductivity and particulate organic matter in water (Tab. 2).

\subsubsection{Taxonomic and functional diversity during the colonization process}

According to the non-metric multidimensional scaling (NMDS) analysis, the colonization process of periphytic ciliates in a temperate floodplain lake can be divided into three phases that differ in the length of duration and community structure (Fig. 6A and B). The first 12 days of community development during the spring period belong to the initial phase of the colonization process (Fig. 6A). This phase in summer period was shorter, and included the first three days of ciliate colonization. The intermediate phase of colonization included days 15-27 during the spring period and days 6-21 during the summer period. The late phase of colonization lasted from day 30 to day 42 during the spring period, while in summer it lasted from day 24 till day 43 . However, differences in the community structure were evident during this phase in summer, suggesting additional sequences in ciliate colonization, one of which lasted from day 24 to day 30, and the second from day 33 to day 43 (Fig. 6B).

The initial phase of colonization in spring was characterized by low values in total ciliate abundance and its slow increase (Fig. 4A). Mobile filter-feeding ciliates consuming mainly bacteria and algae from the periphyton mat (Cinetochilum margaritaceum, Calyptotricha pleuronemoides, Chilodonella uncinata and Ctedoctema acanthocryptum) prevailed in the community until day 9. On days 6 and 9,

Table 2. Spearman correlation coefficients between total ciliate abundance and abiotic and biotic parameters measured in water and periphyton during the spring and summer colonization period. Significant correlations (defined at $* p<0.05, * * p<0.01$ and ${ }^{* * *} p<0.001$ ) are in bold.

\begin{tabular}{|c|c|c|c|}
\hline & Parameters & Total ciliate abundance in spring & Total ciliate abundance in summer \\
\hline \multirow{16}{*}{ Water } & Danube water level & 0.06 & $-0.53 *$ \\
\hline & Lake depth & 0.13 & $-0.83^{* * *}$ \\
\hline & Water transparency & $-0.66^{* *}$ & -0.49 \\
\hline & Water temperature & $0.59^{*}$ & -0.18 \\
\hline & Dissolved oxygen & -0.06 & -0.07 \\
\hline & $\mathrm{pH}$ & -0.45 & 0.14 \\
\hline & Conductivity & -0.17 & $0.68^{* * *}$ \\
\hline & Ammonium & -0.24 & 0.40 \\
\hline & Nitrates & 0.10 & -0.32 \\
\hline & Nitrites & 0.39 & -0.34 \\
\hline & Total nitrogen & 0.08 & 0.14 \\
\hline & Total phosphorus & -0.31 & 0.44 \\
\hline & Chlorophyll $a$ & 0.50 & $0.69^{* *}$ \\
\hline & Total suspended solids & $0.63^{*}$ & 0.46 \\
\hline & Particulate inorganic matter & -0.50 & 0.09 \\
\hline & Particulate organic matter & $0.79^{* * * *}$ & $0.55^{*}$ \\
\hline \multirow{5}{*}{ Periphyton } & Dry weight & 0.45 & -0.15 \\
\hline & Ash weight & 0.45 & -0.21 \\
\hline & Ash-free dry weight & $0.53^{*}$ & -0.07 \\
\hline & Chlorophyll $a$ & $0.54^{*}$ & 0.13 \\
\hline & Chlorophyll $c$ & 0.43 & -0.08 \\
\hline
\end{tabular}


A) SPRING

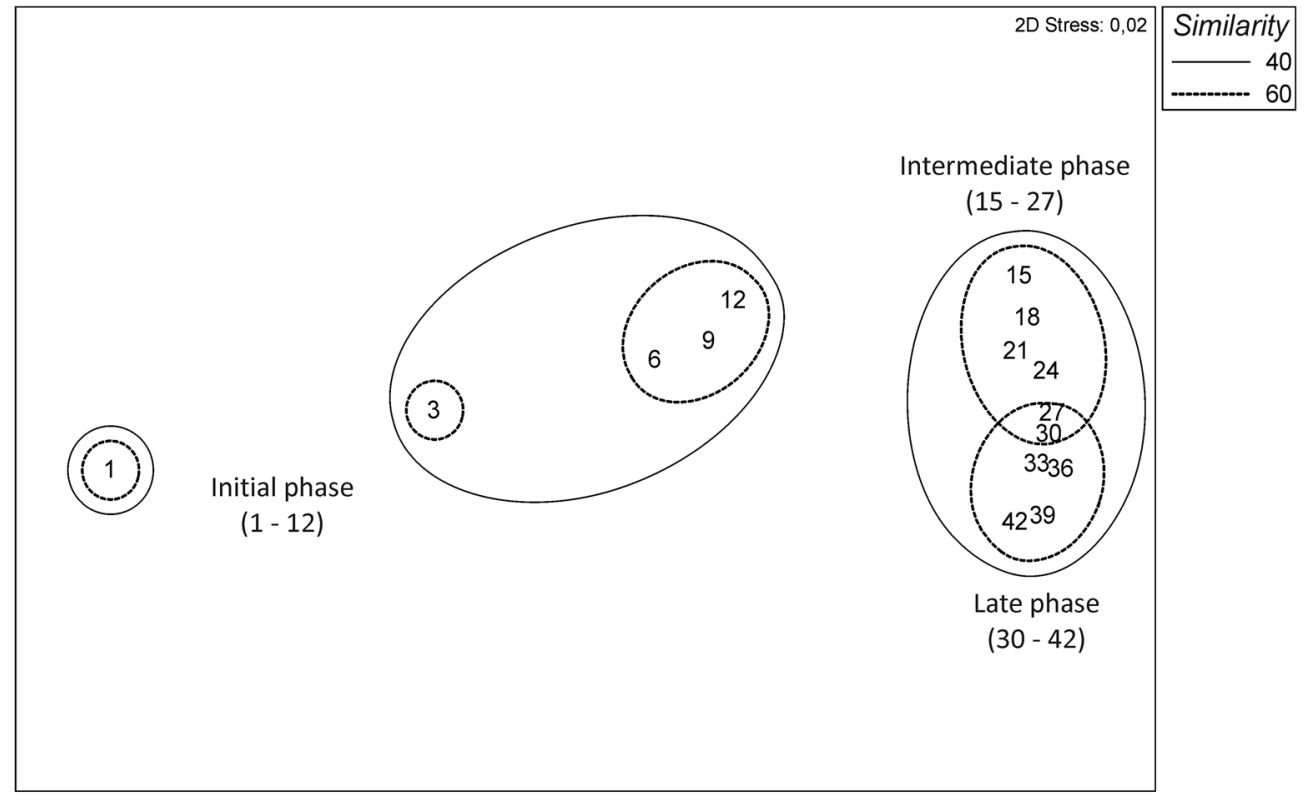

B) SUMMER

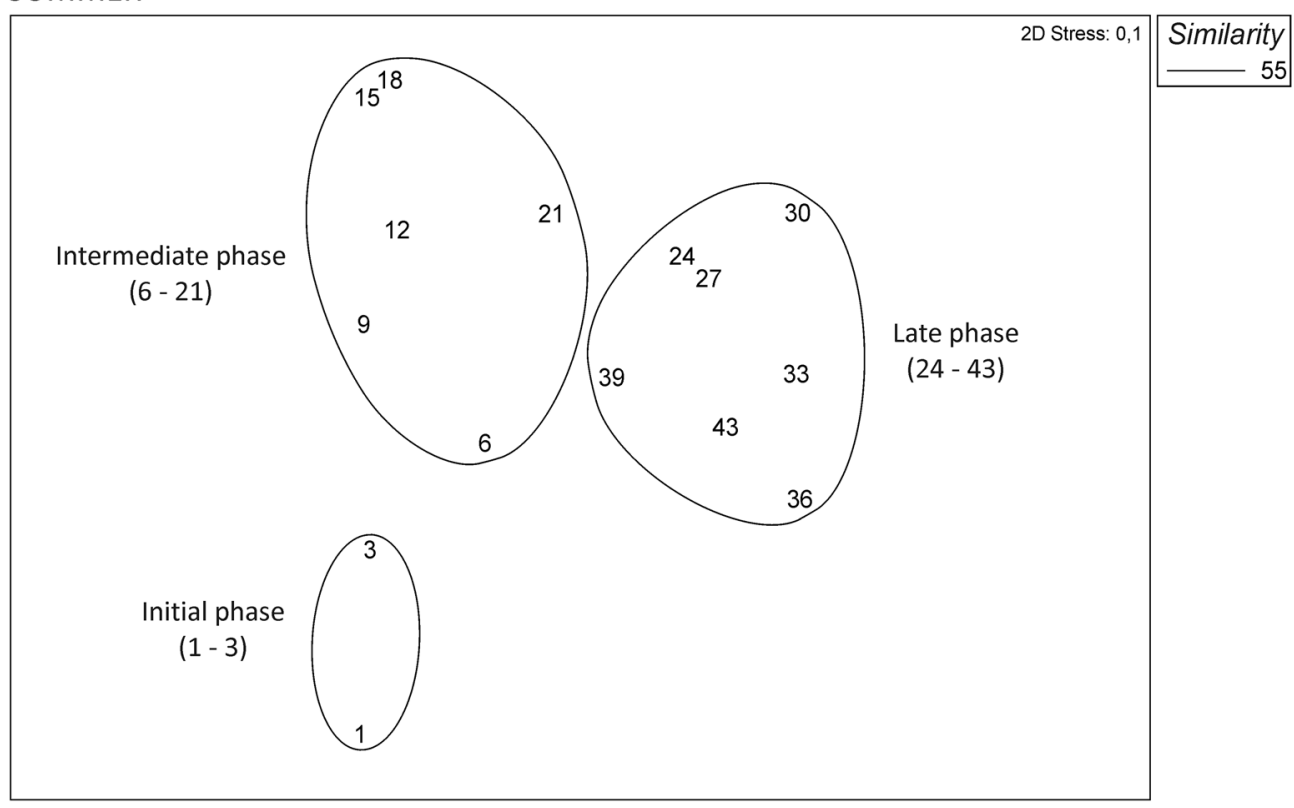

Fig. 6. Non-metric multidimensional scaling (NMDS) plots based on the periphytic ciliate abundance data during (A) spring (day 1-day 42) and (B) summer (day 1-day 43) colonization period in the Lake Sakadaš. Numbers represent days of colonization.

mobile predators (Litonotus spp. and L. cygnus) and omnivores (Euplotes spp. and Frontonia sp.) contributed considerably to the total abundance of ciliates (Figs. 4C, 7A and C). This resulted with the increase in the abundance of raptorial feeders, in addition to filter feeders (Fig. 7E). Sessile ciliates (filter-feeding peritrichs Vorticella campanula and Vorticella spp. 1 (includes $V$. convallaria-complex and $V$. picta)) were also present in periphyton from the onset of colonization, and outnumbered the mobile representatives towards the end of the initial phase (Figs. 4C, 7A and E). The abundance of suctorian Metacineta macrocaulis (diffusion feeder) also increased untill day 12
(Figs. 4C and 7E). Therefore, at the end of the initial phase in spring, bacterivores-algivores were the most abundant, although other trophic groups (predators, bacterivores and omnivores) were also present (Fig. 7C). The initial phase of colonization in summer was shorter than that in spring, and was characterized by a rapid increase in total ciliate abundance and diversity (Fig. 4A and B). Sessile peritrichs (Vorticella convallaria-complex, $V$. campanula, Vorticella spp.2 (includes $V$. aquadulcis-complex and $V$. octava-complex), Pseudovorticella monilata and Epistylis hentscheli) were the dominant ciliates during this phase (Figs. 4D and 7B). 
SPRING
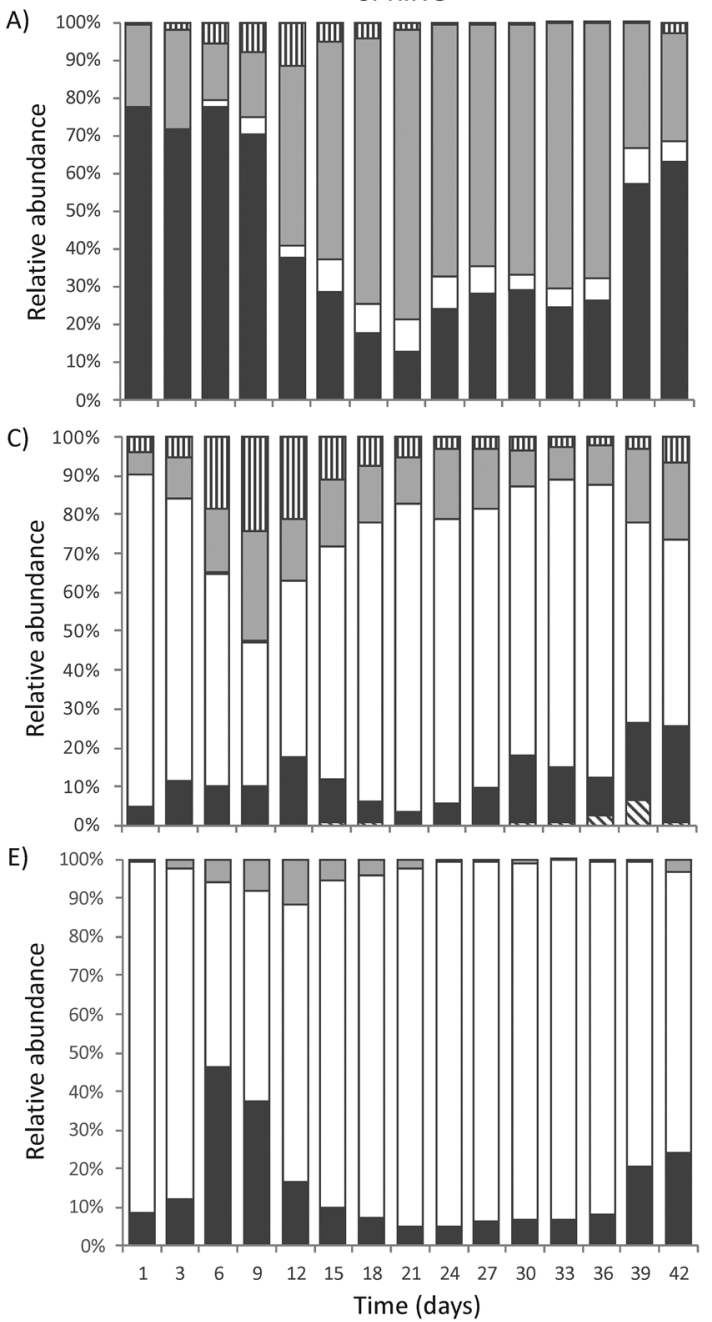

SUMMER
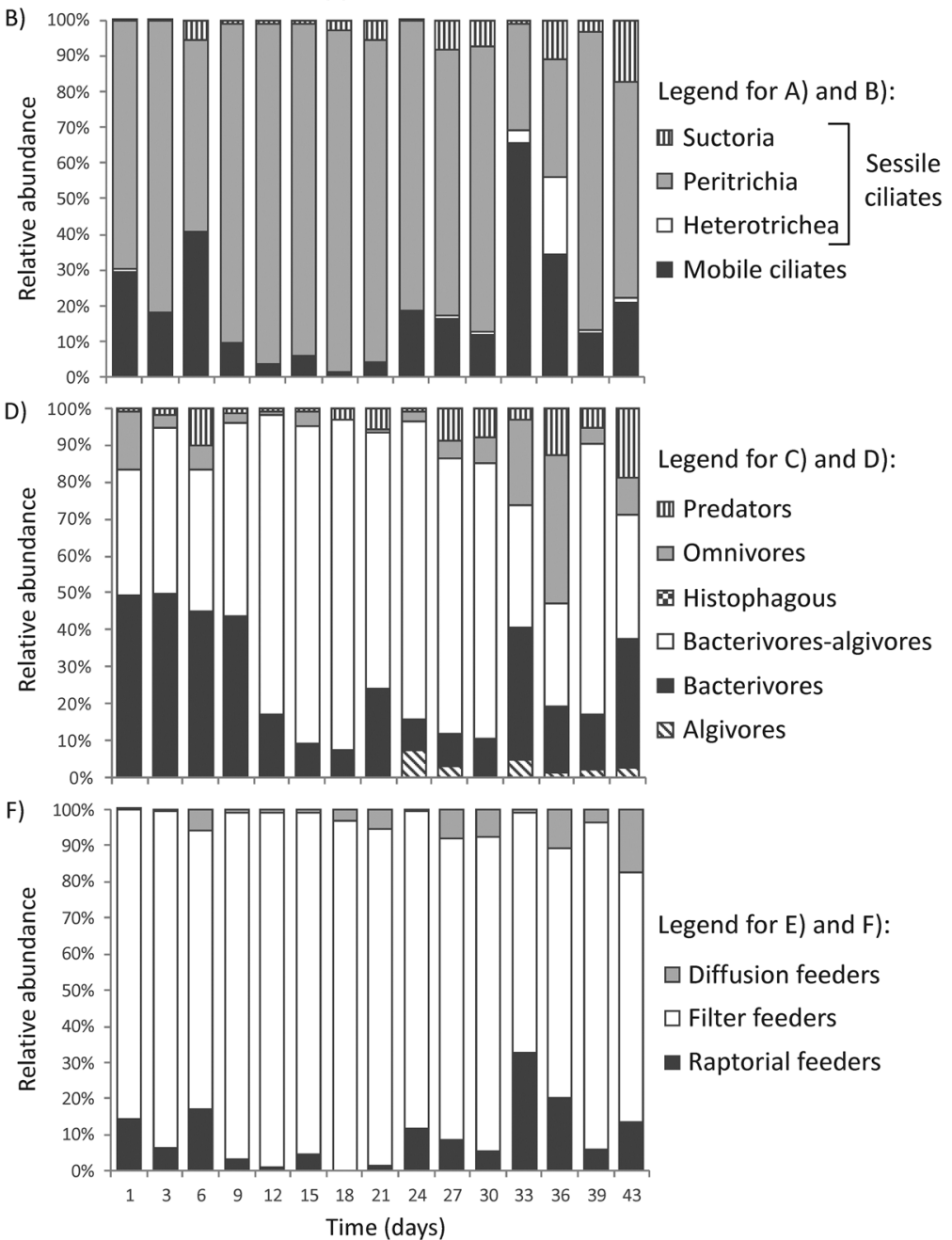

Fig. 7. Variations in the relative abundance of ciliate functional groups defined according to (A, B) life mode (sessile ciliates are represented by Heterotrichea, Peritrichia and Suctoria), (C, D) feeding type and (E, F) food acquisition mechanism during the spring (day 1-day 42) and summer (day 1-day 43) colonization period in the Lake Sakadaš.

Bacterivores and bacterivores-algivores were the most abundant trophic groups, and filter-feeding was the dominant mechanism of food acquisition (Fig. 7D and F). Mobile ciliates (mainly Coleps spp. and swarmers of Peritrichia) also contributed substantially to overall abundance during the initial phase of colonization in summer and at the beginning of intermediate phase (mostly Cyclidium glaucoma) (Figs. 4D and $7 \mathrm{~B})$.

The intermediate phase of both seasons was characterized by a considerable increase in the total ciliate abundance to the maximum, after which the abundance began to decrease (Fig. 4A). Peritrichs Vorticella campanula and Vorticella spp.1 were the most abundant ciliates during this phase in spring (Fig. 4C), indicating that filter-feeding bacterivores-algivores were the dominant functional feeding groups (Fig. 7C and E). In addition to these ciliates, heterotrich Stentor roeselii (filterfeeding omnivore) also substantially contributed to the overall abundance of sessile ciliates (Figs. 4C, 7A, C and E). The intermediate phase in summer was characterized by the lowest ciliate diversity observed during this season (Fig. 4B). An over-dominance of Peritrichia was recorded (Fig. 7B), among which the most abundant representatives were Epistylis chrysemydis, E. hentscheli, E. plicatilis and E. entzii, with the exception of days 15 and 18 when substantially high abundance of Vorticella spp.1 was recorded (Fig. 4D). Initially, bacterivores and bacterivores-algivores were the dominant trophic groups, but then bacterivores-algivores prevailed in the community (Fig. 7D). The most common mode of gathering food particles was filter-feeding (Fig. 7F). At the end of this phase, the suctorian Dendrosoma capitata (predator and diffusion feeder) was among the dominant ciliate species (Figs. 4D, 7D and F).

Total ciliate abundance increased slightly at the beginning of the late phase of colonization in spring, but then decreased towards the end of the colonization period (Fig. 4A). From days 30-36, sessile ciliates (peritrichs Vorticella campanula 
and Vorticella spp.1 and heterotrich Stentor roeselii) were dominant in the periphyton (Fig. 4C). These ciliates contributed substantially to the total abundance on days 39 and 42, however mobile ciliates (Aspidisca cicada, Cinetochilum margaritaceum, Coleps spp., Tachysoma pellionellum and Trithigmostoma spp.) prevailed in the community at this time (Figs. 4C and 7A). Although bacterivores-algivores and filter feeders were the major functional feeding groups during the late phase of colonization in spring, other trophic groups (bacterivores, omnivores, algivores and predators) became more abundant on days 39 and 42, resulting in more diverse trophic structure (Fig. 7C and E). The abundance of raptorial feeders increased toward the end of the spring colonization study, however filter-feeding was still dominant mechanism of food aquisition (Fig. 7E). The late phase of colonization in summer may be divided into two periods characterized by a different ciliate community structure (Figs. 4D and 6B). During the period between day 24 and 30, the total ciliate abundance decreased and the sessile peritrich Epistylis chrysemydis (filter-feeding bacterivore-algivore) outnumbered the other ciliate species (Fig. 4A and D). Dominant ciliates during this period were also suctorians Acineta tuberosa and Tokophrya quadripartita (sessile predators and diffusion feeders) and cyrtophorid Pseudochilodonopsis spp. (mobile algivore and raptorial feeder) (Figs. 4D, 7B, D and F). A significant change in community structure occurred on day 33 when mobile ciliates (Cyclidium glaucoma, Nassula picta, Ctedoctema acanthocryptum and Trochilia minuta) became dominant in the periphyton, although peritrich Epistylis chrysemydis was still among the most abundant representatives (Figs. 4D and 7B). In addition to bacterivores-algivores, bacterivores and omnivores also represented dominant trophic groups (Fig. 7D). Filter feeders were the most abundant ciliates, however raptorial feeders increased significantly in number (Fig. 7F). Changes were also evident on day 36. A prevalence of sessile ciliates was recorded, among which the peritrichs Vorticella campanula and Vorticella spp.2, the heterotrich Stentor roeselii and the suctorian Metacineta micraster were the most abundant. However, mobile ciliates Nassula picta, Calyptotricha pleuronemoides and Coleps spp. also contributed considerably to overall abundance (Figs. 4D and 7B). Trophic structure was diverse, with omnivores being the most abundant trophic group, while filter-feeding was the main way of food acquisition (Fig. 7D and F). On days 39 and 43 sessile ciliates prevailed in periphyton (Fig. 7B). Peritrichs (Vorticella spp.1, Vorticella spp.2, V.campanula, Epistylis chrysemydis, E. plicatilis and $E$. entzii) were the dominant representatives, although abundance of suctorian Metacineta micraster increased at the end of summer colonization study (Fig. 4D). Filter-feeding bacterivores-algivores were dominant on day 39 , while on day 43 there was a high abundance of bacterivores, bacterivores-algivores and predators with filter-feeding as the predominant food acquisition mechanism (Fig. 7D and F).

According to the analysis of similarity (ANOSIM), the structure of the periphytic ciliate communities was significantly different between the two colonization periods $(R=0.564 ; p<0.001)$. The SIMPER analysis revealed that peritrichs Epistylis chrysemydis, Vorticella spp.2, Vorticella spp.1, Epistylis plicatilis, Vorticella campanula, Vorticella convallaria-complex and Epistylis hentscheli (20.98\%) and the heterotrich Stentor roeselii (2.4\%) contributed most to the dissimilarity between spring and summer ciliate communities.

\subsubsection{The relatedness of colonization process to environmental factors}

In the Redundancy Analysis (RDA) for the spring colonization period, the two main axes explained $74.6 \%$ of the variance in the species data (Fig. 8A). A significant relationship between environmental variables and dominant ciliate species is demonstrated by high species-environment correlations for axes 1 (0.974) and 2 (0.972) (Fig. 8A). The first RDA axis was significantly correlated with particulate organic matter in water $(-0.76)$, inorganic matter in periphyton $(-0.77)$ and water temperature $(-0.59)$, with the latter two parameters being also correlated strongly with the second RDA axis $(0.54$ and 0.64 , respectively). The initial phase of colonization in spring, characterized by the low abundance of ciliates, was associated with decreasing Danube water level and low values of water temperature and inorganic matter in periphyton. The periphytic ciliate community during the intermediate phase was influenced by the high concentrations of particulate organic matter in the water and total nitrogen, as well as by higher water temperature and low water transparency. The late phase was associated with higher values of water temperature, inorganic matter in periphyton and Danube water level (Fig. 8A).

The high species-environment correlations for axes 1 (0.964) and 2 (0.950) indicate a significant relationship between dominant ciliate taxa and environmental variables during the summer colonization process (Fig. 8B). The two main axes of RDA explained $54.8 \%$ of the variance in the species data. The first RDA axis was significantly correlated with lake depth $(0.72)$ and conductivity $(-0.79)$, while the second RDA axis was in significant correlation with chlorophyll $a$ in periphyton $(-0.88)$ and periphytic biomass, i.e. inorganic and organic matter in periphyton $(-0.61)$. The colonization process of ciliates during the initial phase was related to the high water temperature and low periphytic biomass (inorganic and organic matter in periphyton) and chlorophyll $a$ concentration in periphyton. The intermediate phase of community development was characterized by the high values of conductivity and water temperature and the low values of lake depth. The late phase of colonization was associated with high periphytic biomass (inorganic and organic matter in periphyton) and periphytic chlorophyll $a$ concentration, however at the end of the colonization process, the increase in lake depth was significant for the ciliate community development (Fig. 8B).

\section{Discussion}

The results of our study show that periphyton colonization in floodplain lakes is a rapid and dynamic process, requiring appropriate sampling dynamics. We found that peritrichs, ciliates commonly found in freshwater periphyton (Strüder-Kypke, 1999; Kathol et al., 2011; Safi et al., 2014; Vlaičević et al., 2017) were the dominant ciliate representatives of periphytic communities in a temperate 
A) SPRING

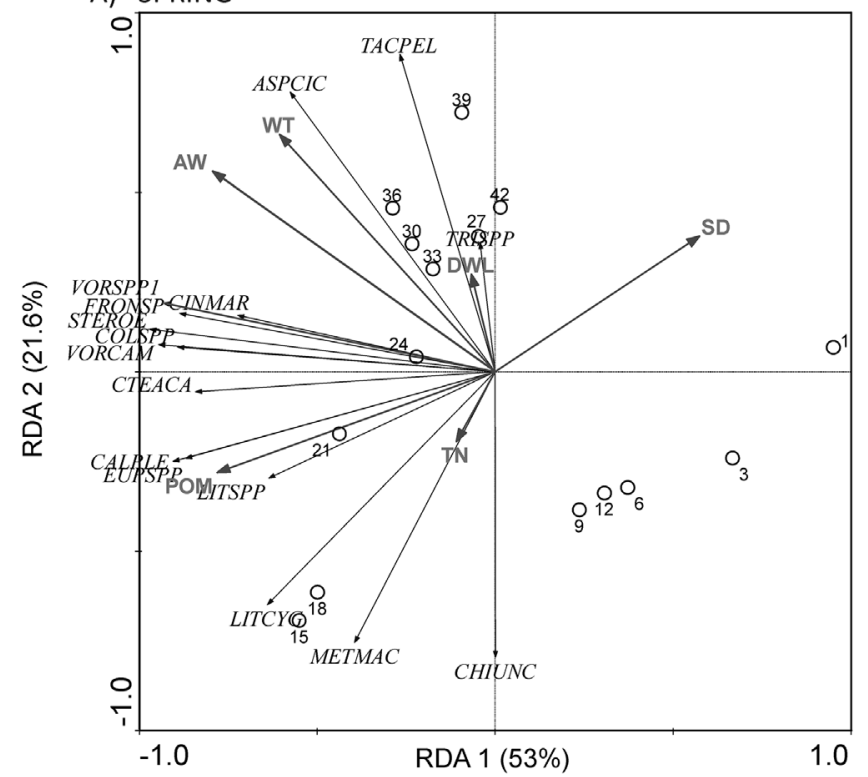

B) SUMMER

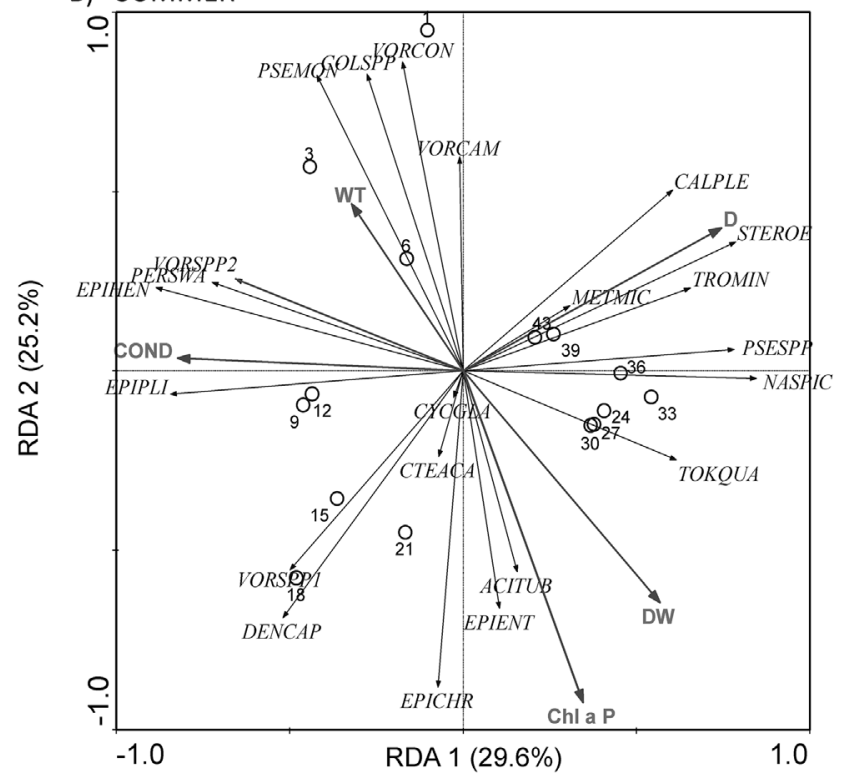

Fig. 8. Redundancy Analysis (RDA) of ciliate abundance data during (A) spring (day 1-day 42) and (B) summer (day 1-day 43) colonization period in the Lake Sakadaš. The plots show the distribution of dominant ciliate taxa along the first and second RDA axes in relation to the statistically significant environmental parameters: AW (ash weight - inorganic matter in periphyton), Chl $a$ P (chlorophyll $a$ in periphyton), COND (conductivity), D (lake depth), DW (dry weight - inorganic + organic matter in periphyton), DWL (Danube water level), POM (particulate organic matter), SD (water transparency), TN (total nitrogen), WT (water temperature). Dominant ciliate taxa codes (explained in Fig. 4) are italicized. Open circles indicate days of colonization.

floodplain lake, Lake Sakadaš (Fig. 7A and B). Among them, solitary Vorticella and colony forming Epistylis were the most abundant genera, represented also by the highest diversity. While Vorticella species were present in every phase of the colonization process in both seasons during our study, species of genus Epistylis were present only during the intermediate and late phase of summer colonization process (Fig. 4C and D). A similar colonization pattern of these two genera, according to which solitary peritrichs can reach high abundances at any stage during the colonization process, while colonial peritrichs are typical for later stages of the community development, was also recorded in a Neotropical shallow lake (Safi et al., 2014). Kathol et al. (2011) detected higher abundance of Vorticella species in winter periphyton samples in River Rhine, while Epistylis spp. dominated in summer samples.

In terms of functional groups, we found that the most abundant ciliates in the floodplain lake periphyton were sessile filter feeders (Fig. 7A, B, E and F), i.e. ciliates that live attached to the substrate and collect food particles (mainly bacteria and algae) suspended in the surrounding water column (e.g. Vorticella spp. and Epistylis spp.). These planktivorous ciliates may play a significant ecological role as mediators of organic matter and energy flow from plankton to benthos in floodplain habitats, already recognized in other freshwater systems (Weitere et al., 2003; Früh et al., 2011; Kathol et al., 2011). Bacterivores and bacterivores-algivores, which dominated throughout the study (Fig. 7C and D), are characteristic of highly productive (eutrophic and hypertrophic) lake ecosystems (Kalinowska, 2004). Suspension-feeding bacterivores and bacterivores-algivores can significantly impact the lake plankton community (Safi et al., 2014), making carbon fixed in bacteria and algae available to organisms of higher trophic levels (Sigee, 2005; Weitere et al., 2018).

Despite the overall dominance of peritrichs, the structure of the ciliated community changed during colonization (Figs. 4C and $\mathrm{D}, 7 \mathrm{~A}-\mathrm{F}$ ), due to fluctuations of certain abiotic and biotic parameters including water temperature, Danube water level, lake depth, water transparency, conductivity, total suspended solids (especially organic matter), concentration of chlorophyll $a$ in water and periphyton, and periphytic biomass. This provided a more detailed insight into the dynamics of periphytic ciliates and revealed the prevalence of diverse taxonomic and functional groups over the course of colonization process. Seasonality of periphytic communities in temperate regions has been extensively studied (Sigee, 2005; Mora-Gómez et al., 2016), and seasonal shifts in community structure and dynamics have also been found for periphytic ciliates (Safi et al., 2014; Neury-Ormanni et al., 2020; Sikder et al., 2020). In this study, the taxonomic composition of ciliate communities significantly differed between the spring and summer seasons, confirming that seasonality strongly influences the ciliate colonization process.

The most significant changes in the taxonomic and functional composition of the ciliate community, as well as in the total ciliate abundance, coincided with changes in the hydrological regime, recognizing them as another important environmental factor affecting periphytic ciliates. Certain environmental factors, which were found to be most important for periphytic ciliate colonization in the investigated Lake Sakadaš, substantially differed between two hydrological periods. During the flooding periods, an increase in lake depth, 
water transparency and nutrient concentrations was observed, while conductivity, chlorophyll $a$ concentration, total suspended solids and particulate organic matter had higher values during the low-water periods (Fig. 2A-C, G-I, K, L-P). In both seasons, the chlorophyll a concentration positively correlated with the concentration of particulate organic matter (Tab. 1), indicating that organic particles in the water are largely derived from planktonic algae (Aspetsberger et al., 2002). In Lake Sakadaš, the period of low water levels represents a more stable hydrological phase, while during the period of high water levels, flood pulses alter the lake environment and consequently disturb the structure of various lake communities, including planktonic and periphytic bacteria (Vidaković et al., 2011; Palijan, 2012), planktonic and periphytic algae (Mihaljević and Stević, 2011; Žuna Pfeiffer et al., 2015) and zooplankton (Galir and Palijan, 2012). As these organisms represent important food sources for periphytic ciliates (Norf et al., 2009a; Früh et al., 2011; Villanueva et al., 2011), changes in their structure are also reflected in the structure of the ciliate community. According to our results, during the later stages of the colonization process in both seasons, the lowest values of the total ciliate abundance were recorded during the flooding periods when low concentrations of chlorophyll $a$ and particulate organic matter in water were detected.

The three phases of the colonization process termed as initial, intermediate and late phase (Fig. 6A and B) were also recorded in other studies on the colonization process of periphytic ciliates (Früh et al., 2011; Zhang et al., 2012, 2013; Sikder et al., 2019). Although in both seasons periphyton started to develop rapidly after the substrates were immersed in the lake (the initial phase began already within the first 24 hours of substrate exposition), faster colonization (Fig. 5) followed by higher abundance and diversity of ciliates (Fig. 4A and B) was recorded during the summer initial phase. According to the MacArthur-Wilson equilibrium model (Fig. 5), ciliate colonization was indeed remarkably rapid during the summer, indicating the need to study the colonization process at even shorter time intervals (every few hours) during the initial phase to more accurately determine the colonization dynamics. This rapid colonization and increase in the ciliate abundance and diversity is most likely associated with the higher values of water temperature, as shown by the results of statistical analysis (Fig. 8B). Water temperature has a significant impact on the rate of metabolic processes, including feeding and growth, so seasonal variations in temperature values can lead to significant differences in ciliate community dynamics (Gong et al., 2005; Norf and Weitere, 2010). Beech and Landers (2002) and Norf et al. (2007) also found that increasing water temperature stimulates and accelerates ciliate colonization on artificial substrates. The period of decreasing water level and cessation of the flood phase in the Lake Sakadaš, which was registered at the beginning of our two experiments, is characterized by the high density of planktonic bacteria (Palijan, 2010). Under such conditions, the rapid settlement of bacteria on new substrates can be expected, creating a favorable environment for periphytic ciliates and stimulating their colonization (Norf et al., 2009b; Villanueva et al., 2011). Algae represent another important food source for periphytic ciliates (Früh et al., 2011; Kanavillil and Kurissery, 2013), so their presence on the substrates is of great importance for the ciliate community development. Simultaneously with our research, the study of algal community on glass slides was conducted in the Lake Sakadaš and the results indicated that algae colonized the glass slides rapidly, with faster colonization observed also during summer conditions (Mihaljević and Žuna Pfeiffer, 2012; Žuna Pfeiffer et al., 2013). Therefore, the high bacterial density in lake water and the early presence of bacteria and algae on the substrates explain the rapid colonization by ciliates and the dominance of bacterivorous and bacterivorous-algivorous species during the initial colonization. However, the share of bacterivores in relation to bacterivores-algivores was higher during the summer initial phase (Fig. $7 \mathrm{C}$ and D). At that time, the bacterial degradation of organic matter in water was more intense, as indicated by the much lower values of dissolved oxygen concentration and $\mathrm{pH}$ than in the spring. Under such conditions the high abundance of bacteria could stimulate the colonization of ciliates which feed mainly on bacteria (Früh et al., 2011; Kanavillil and Kurissery, 2013).

In both seasons, the colonization order of periphytic ciliates did not completely follow the general pattern, according to which the first colonizers are mainly small mobile bacterivorous species, followed by larger sessile species with more diverse diet and filter-feeding and predatory mechanism of food gathering (Strüder-Kypke, 1999; Früh et al., 2011; Zhang et al., 2012; Vlaičević et al., 2017). The early spring and summer phase differed with respect to the ciliate taxa which were the first colonizers of the glass slides (Fig. 4C and D). The first colonizers represent pioneers in the colonization of new microhabitats and form the most abundant populations at the beginning of community development (Strüder-Kypke and Schönborn, 1999). Mobility is an important characteristic of initial colonizers, allowing them the contact with the substrate and possibility to attach (Sigee, 2005). Therefore, small, mobile ciliates are particularly important for the initial colonization of exposed surfaces, and these ciliates were dominant during the spring initial phase in our study (Figs. 4C and 7A). The abundance of mobile predators and omnivores also increased quite soon after the substrate immersion (Fig. 7A and C), most probably due to sufficient food in the periphyton. All of these ciliate representatives are primarily benthivores, which feed directly on the surface-associated prey, so the periphyton mat acted as the main food source for ciliates during the initial phase in spring. Peritrichs were also present in the periphyton from the first day of colonization and became dominant at the end of the spring initial phase (Fig. 7A). These ciliates, although sessile, can reach high abundances in the early phase of community development (Safi et al., 2014), because their life cycle involves a free-swimming mobile phase, which is important for the dispersal and colonization of new substrates (Sigee, 2005). Although mobile ciliates were detected in the periphyton during the summer initial phase, peritrichs dominated throughout the entire phase (Fig. 7B). Their dominance is most likely related to the higher water temperature, which usually stimulates peritrich colonization, as well as with the increased food availability, most probably the higher density of planktonic bacteria (Beech and Landers, 2002; Landers and Phipps, 2003; Villanueva et al., 2011). Feeding and growth rates increase with higher water temperatures so periphytic ciliates respond more quickly to the 
resources availability (Norf et al., 2009b; Früh et al., 2011). Therefore, during the initial summer phase, sessile filter feeders (planktivores), otherwise characteristic for the later phases of community development, were the most abundant ciliates in the periphyton (Fig. 7B and F), and planktonic organisms represented the main food source for ciliates.

A deviation from the general trend in the colonization process was also observed in the late phase of community development in both seasons. In spring period, such divergence occurred at the very end of colonization study (on days 39 and 42), while in summer it was registered on day 33 (Figs. 4C and D, 7A and B). At that time mobile benthivorous ciliates outnumbered the sessile planktivores and became dominant in the periphytic community. This shift coincided with the changes in the hydrological regime - the beginning of the minor to moderate flooding in spring and extremely high flooding in summer (Fig. 2A). The development of planktonic microorganisms (bacterioplankton and phytoplankton) in the Lake Sakadaš is less pronounced during the high-water periods, most likely due to the dilution and washout effect of the flood (Mihaljević et al., 2010; Mihaljević and Stević, 2011; Palijan, 2012). As these organisms represent one of the major food source for periphytic ciliates, significant changes in the abundance and functional composition of periphytic ciliate community could have been expected to occur during the flooding periods. Mobile benthivores, which feed directly on the surface-associated prey, became dominant during the high-water periods (Figs. 2A, 7A and B), and periphyton mat provided the main food source for ciliates in such conditions. However, during the more stable periods of low water (Fig. 2A) when the amount of organic particles in the water was high (Fig. 2K) and communities of planktonic bacteria and algae were likely well developed, sessile filterfeeding (planktivorous) species were dominant functional groups in the periphyton (Fig. 7A, B, E and F). Exceptionally, at the beginning of the flooding period in summer, from day 18 of colonization (Fig. 2A), sessile suspension-feeding ciliates were more abundant than mobile benthivores (Fig. 7B), most probably because the concentration of chlorophyll $a$ and organic particles in water was still high (Fig. $2 \mathrm{H}$ and $\mathrm{K}$ ), so there was sufficient amount of food to support the peritrich growth. Such relationship between functional composition of periphytic ciliate community and availability of planktonic bacteria and algae was also established by Kathol et al. (2011). Major changes in the ciliate community structure were recorded on day 33 during summer experiment (Figs. 4A and $\mathrm{D}, 7 \mathrm{~B}, \mathrm{D}$ and $\mathrm{F}$ ) when the extremely high flood pulse occurred (Fig. 2A), resulting in the appearance of metaphyton and macrophytes in the Lake Sakadaš and formation of dense mats at the research station. The flood pulses usually lead to an increase in the nutrient concentration in the floodplain waterbodies, either by direct input through river floodwaters, or as a result of the input from the surrounding terrestrial zone (Hein et al., 2004; Mihaljević et al., 2010; Peršić et al., 2010). We also recorded increased nutrient concentrations during the periods of high water level (Fig. 2A, L-P), and such conditions likely stimulated the growth and spreading of lake autotrophic organisms (Bogut et al., 2005; Mihaljević et al., 2010; Peršić et al., 2010). This caused the establishment of specific environmental conditions in the Lake Sakadaš and consequently affected the periphyton growth and ciliate community structure. A substantial decrease in periphytic biomass and chlorophyll concentrations followed the spread of metaphyton and macrophytes (Fig. 3A-E), suggesting that a shift from accrual to loss phase occurred. Such low values of periphytic biomass are commonly found in aquatic habitats characterized by frequent disturbance, well-developed macrophyte stands and intensive grazing (Higgins and Hann, 1995; McCormick et al., 1998; Vermaat, 2005; Wetzel, 2005). Dense stands of metaphyton and macrophytes negatively affected periphytic communities, most likely by reducing underwater light availability and uptaking a large part of the nutrients, thus suppressing the growth of periphytic autotrophs (Wetzel, 2001; van der Valk, 2006). Further, these stands supported a high abundance and diversity of aquatic invertebrates, including Nematoda, Gastropoda, Oligochaeta, Cladocera, Copepoda and Insecta (Vidaković et al., 2017), whose grazing activities could substantially reduce periphytic biomass (Bogut et al., 2005; Hillebrand, 2009; Mahdy et al., 2014). Consequently, rather low values of ciliate abundance were determined on glass slides during the late phase of colonization in summer (Fig. 4A). In addition to a significant reduction in periphytic biomass and high grazing pressure, another possible reason for the decrease in ciliate abundance on glass slides was more favorable conditions in the metaphyton and macrophytes stands by means of the available surfaces for the attachment and larger amounts of food (Mieczan, 2010). Besides, lower density of planktonic bacteria and algae in the lake water during this high-water period, i.e. reduced food availability, could be another reason for the decrease of periphytic ciliate abundance. Supporting this hypothesis, the functional composition of ciliate community also changed in such conditions, and the trophic structure became more diverse (Fig. 7B, D and F). When metaphyton and macrophytes were registered at the sampling location for the first time (on day 33), mobile ciliates were dominant in periphyton (Fig. 7B), and a substantial increase in the abundance of raptorial feeders was recorded (Fig. 7F), although filter feeders were still the most abundant. At this time benthivores were the dominant group and periphytic food sources were more important than planktonic. However, as periphytic biomass and chlorophyll concentrations decreased towards the end of the summer colonization (Fig. 3A-E), and chlorophyll $a$ concentration in water increased (Fig. 2H), mobile benthivores became less represented in periphyton, while sessile planktivores, mainly peritrichs, became dominant again (Fig. 7B). Besides them, sessile filter-feeding omnivores (heterotrich Stentor roeselii) and diffusion-feeding predators (suctorians) considerably contributed to the total ciliate abundance (Fig. 7B, D and F). Such diverse trophic structure is usually found during the later phases of colonization process (Strüder-Kypke, 1999; Früh et al., 2011; Vlaičević et al., 2017).

\section{Conclusion}

The results of the present study show that the colonization process and structure of the periphytic ciliate community in temperate floodplain lake ecosystems mostly depend on water temperature (seasonality), food availability (in plankton and periphyton), and periphyton morphology, as in many other freshwater ecosystems. However, the results also indicate the 
high importance of changes in the floodplain hydrology in structuring periphytic ciliate community during the colonization of newly exposed substrates. Floods alter the lake environment, thereby disturbing communities of planktonic bacteria and algae, which are major food source for periphytic ciliates. In addition, floods can stimulate the development of autotrophic organisms in the lake, such as metaphyton and macrophytes, again affecting the periphytic ciliate community. Under flooding conditions mobile benthivorous (surfacefeeding) ciliates become dominant, and periphyton matrix represents the main source of food and shelter for ciliates. However, during low water levels and more stable conditions in the lake, sessile planktivorous ciliates (mainly peritrichs) prevail in the periphytic communities, and planktonic microorganisms become a more important source of food. In such conditions periphytic ciliates play an important role in the pelagic-benthic coupling. In conclusion, the colonization process of periphytic ciliates in this hydrologically driven and dynamic freshwater ecosystem does not follow the general pattern of colonization sequence. Knowledge of the effects of flood events on the community of phagotrophic protists, particularly ciliates, is limited. Our results shed light on the complex colonization process, the influence of floodplain hydrology, and community structure of periphytic ciliates, thus contributing significantly to a better understanding of microbial ecology in floodplain lake ecosystems. Determining what role phagotrophic protists play in the pelagic-benthic coupling in temperate floodplain ecosystems is a challenge for future research and necessary to better understand the efficiency of energy and carbon transfer and the effects on higher trophic levels of aquatic food webs.

Acknowledgements. This research was supported by the Ministry of Science, Education and Sport of the Republic of Croatia, research project No. 285-0000000-2674. We are grateful to project leader Prof. Jasna Vidaković for her support. We would like to thank the members of the Subdepartment of Water Ecology (Department of Biology, Josip Juraj Strossmayer University of Osijek) for help in the field and laboratory work. We are grateful to Prof. Biserka Primc for her helpful advice that improved the manuscript considerably. We thank the employees of Eco-laboratory in Vodovod Osijek Ltd for their help with the water chemistry analysis. We would like to thank two anonymous reviewers for their helpful comments that substantially improved the manuscript.

\section{References}

Ackermann B, Esser M, Scherwass A, Arndt H. 2011. Long-term dynamics of microbial biofilm communities of the River Rhine with special references to ciliates. Int Rev Hydrobiol 96: 1-19.

Adl SM, Simpson AGB, Lane CE, Lukeš J, Bass D, Bowser SS, et al. 2012. The revised classification of eukaryotes. J Eukaryot Microbiol 59: 429-514.

APHA (American Public Health Association) 1985. Standard Methods for the Examination of Water and Wastewater. American Public Health Association, Washington, DC.

Arndt H, Schmidt-Denter K, Auer B, Weitere M. 2003. Protozoans and Biofilms. In Krumbein WE, Paterson DM, Zavarzin GA, eds.
Fossil and Recent Biofilms, Kluwer Academic Publ, Dordrecht, 161-179.

Aspetsberger F, Huber F, Kargl S, Scharinger B, Peduzzi P, Hein T. 2002. Particulate organic matter dynamics in a river floodplain system: Impact of hydrological connectivity. Arch Hydrobiol 156: $23-42$.

Azim ME, Beveridge MCM, van Dam AA, Verdegem MCJ. 2005. Periphyton and Aquatic Production: An Introduction. In Azim ME, Verdegem MCJ, van Dam AA, Beveridge MCM, eds. Periphyton: Ecology, Exploitation and Management, CAB International, CABI Publishing, Wallingford, Oxfordshire, UK, 1-13.

Beech CD, Landers SC. 2002. Ciliated protozoan colonization of substrates from Dauphin Island, Alabama. Europ J Protistol 38: 83-89.

Bogut I, Vidaković J, Palijan G. 2005. Metaphyton invertebrate fauna at the eulittoral of Lake Sakadaš (Kopački rit Nature Park, Croatia). Hrvatske vode/Croat Wat 13: 153-157.

Böhme A, Risse-Buhl U, Küsel K. 2009. Protists with different feeding modes change biofilm morphology. FEMS Microbiol Ecol 69: $158-169$.

Cairns J Jr, Dahlberg ML, Dickson KL, Smith N, Waller WT. 1969. The relationship of fresh-water protozoan communities to the MacArthur-Wilson equilibrium model. Am Nat 103: 439-454.

Carlson RE, Simpson J. 1996. A Coordinator's Guide to Volunteer Lake Monitoring Methods, North American Lake Management Society, $96 \mathrm{p}$.

Clarke KR, Gorley RN. 2006. PRIMER v6: User Manual/Tutorial. PRIMER-E, Plymouth.

Coppellotti O, Matarazzo P. 2000. Ciliate colonization of artificial substrates in the Lagoon of Venice. J Mar Biol Ass UK 80: 419-427.

Costerton JW, Cheng KJ, Geesey GG, Ladd TI, Nickel JC, Dasgupta M, et al. 1987. Bacterial biofilms in nature and disease. Annu Rev Microbiol 41: 435-464.

Esteban GF, Finlay BJ, Warren A. 2015. Free-Living Protozoa. In Thorp JH, Rogers DC, eds. Thorp and Covich's Freshwater Invertebrates: Ecology and General Biology, fourth ed., vol. 1, Academic Press, Elsevier Inc., Amsterdam, Boston, Heidelberg, London, New York, Oxford, Paris, San Diego, San Francisco, Singapore, Sydney, Tokyo, 113-131.

Finlay BJ, Esteban GF. 1998. Freshwater protozoa: biodiversity and ecological function. Biodivers Conserv 7: 1163-1186.

Foissner W, Blatterer H, Berger H, Kohmann F. 1991. Taxonomische und ökologische Revision der Ciliaten des Saprobiensystems Band I: Cyrtophorida, Oligotrichida, Hypotrichia, Colpodea, Informationsberichte des Bayer Landesamtes für Wasserwirtschaft, München, $478 \mathrm{p}$.

Foissner W, Berger H, Kohmann F. 1992. Taxonomische und ökologische Revision der Ciliaten des Saprobiensystems - Band II: Peritrichia, Heterotrichida, Odontostomatida, Informationsberichte des Bayer Landesamtes für Wasserwirtschaft, München, 502 p.

Foissner W, Berger H, Kohmann F. 1994. Taxonomische und ökologische Revision der Ciliaten des Saprobiensystems Band III: Hymenostomata, Prostomatida, Nassulida, Informationsberichte des Bayer Landesamtes für Wasserwirtschaft, München, $548 \mathrm{p}$.

Foissner W, Berger H, Blatterer H, Kohmann F. 1995. Taxonomische und ökologische Revision der Ciliaten des Saprobiensystems Band IV: Gymnostomatea, Loxodes, Suctoria, Informationsberichte des Bayer Landesamtes für Wasserwirtschaft, München, $540 \mathrm{p}$.

Foissner W, Berger H. 1996. A user-friendly guide to the ciliates (Protozoa, Ciliophora) commonly used by hydrobiologists as 
bioindicators in rivers, lakes, and waste waters, with notes on their ecology. Freshw Biol 35: 375-482.

Früh D, Norf H, Weitere M. 2011. Response of biofilm-dwelling ciliate communities to enrichment with algae. Aquat Microb Ecol 63: 299-309.

Galir A, Palijan G. 2012. Change in metazooplankton abundance in response to flood dynamics and trophic relations in Danubian floodplain lake (Kopačk Rit, Croatia). Pol J Ecol 60: 777-787.

Gong J, Song W, Warren A. 2005. Periphytic ciliate colonization: annual cycle and responses to environmental conditions. Aquat Microb Ecol 39: 159-170.

Harmsworth GC, Sleigh MA. 1993. Colonization of non-living surfaces in streams by peritrich ciliates. Eur J Protistol 29: 294-301.

Hein T, Baranyi C, Reckendorfer W, Schiemer F. 2004. The impact of surface water exchange on the nutrient and particle dynamics in side-arms along the river Danube, Austria. Sci Total Environ 328: 207-218.

Higgins S, Hann BJ. 1995. Snail grazer-periphyton interactions: the effects of macrophyte removal, inorganic nutrient addition, and organic nutrient addition. UFS (Delta Marsh) Annual Report 30: $28-37$.

Hillebrand H. 2009. Meta-analysis of grazer control of periphyton biomass across aquatic ecosystems. J Phycol 45: 798-806.

Iwaniec DM, Childers DL, Rondeau D, Madden CJ, Saunders C. 2006. Effects of hydrologic and water quality drivers on periphyton dynamics in the southern Everglades. Hydrobiologia 569: 223-235.

Junk WJ, Bayley PB, Sparks RE. 1989. The Flood Pulse Concept in River-Floodplain Systems. In: Dodge DP, ed. Proceedings of the International Large River Symposium (LARS). Canadian Special Publication of Fisheries and Aquatic Science, Ontario, Canada, 110-127.

Kalinowska K. 2004. Bacteria, nanoflagellates and ciliates as components of the microbial loop in three lakes of different trophic status. Pol J Ecol 52: 19-34.

Kanavillil N, Kurissery S. 2013. Dynamics of grazing protozoa follow that of microalgae in natural biofilm communities. Hydrobiologia 718: 93-107.

Kathol M, Fischer H, Weitere M. 2011. Contribution of biofilmdwelling consumers to pelagic-benthic coupling in a large river Freshw Biol 56: 1160-1172.

Kreutz M, Foissner W. 2006. Protozoological Monographs: The Sphagnum Ponds of Simmelried in Germany: A Biodiversity HotSpot for Microscopic Organisms, Shaker Verlag, Germany, $267 \mathrm{p}$.

Landers SC, Phipps SW. 2003. Ciliated protozoan colonization of substrates from Weeks Bay, Alabama. Gulf Mex Sci 21: $79-85$.

Larned SC. 2010. A prospectus for periphyton: recent and future ecological research. J N Am Benthol Soc 29: 182-206.

Lepš J, Šmilauer P. 2003. Multivariate Analysis of Ecological Data using CANOCO, Cambridge University Press, New York.

Liboriussen L. 2003. Production, regulation and ecophysiology of periphyton in shallow freshwater lakes, $\mathrm{PhD}$ thesis, National Environmental Research Institute, Denmark, $48 \mathrm{p}$.

Luef B, Aspetsberger F, Hein T, Huber F, Peduzzi P. 2007. Impact of hydrology on free-living and particle-associated microorganisms in a river floodplain system (Danube, Austria). Freshw Biol 52: 1043-1057.

MacArthur RH, Wilson EO. 1963. An equilibrium theory of insular zoogeography. Evolution 17: 373-387.
Mahdy A, Scharfenberger U, Adrian R, Hilt S. 2014. Experimental comparison of periphyton removal by chironomid larvae and Daphnia magna. Inland Waters 5: 81-88.

McCormick PV, Shuford III RBE, Backus JG, Kennedy WC. 1998. Spatial and seasonal patterns of periphyton biomass and productivity in the northern Everglades, Florida, U.S.A. Hydrobiologia 362: 185-208.

Mieczan T. 2005. Periphytic ciliates in littoral zone of three lakes of different trophic status. Pol J Ecol 53: 489-502.

Mieczan T. 2010. Periphytic ciliates in three shallow lakes in Eastern Poland: a comparative study between a phytoplankton-dominated lake, a phytoplankton-macrophyte lake and a macrophytedominated lake. Zool Stud 49: 589-600.

Mihaljević M, Getz D, Tadić Z, Živanović B, Gucunski D, Topić J, et al. 1999. Kopački rit - Pregled istraživanja i bibliografija, Hrvatska akademija znanosti i umjetnosti, Zagreb, 188 p.

Mihaljević M, Špoljarić D, Stević F, Cvijanović V, Hackenberger Kutuzović B. 2010. The influence of extreme floods from the River Danube in 2006 on phytoplankton communities in a floodplain lake: Shift to a clear state. Limnologica 40: 260-268.

Mihaljević M, Stević F. 2011. Cyanobacterial blooms in a temperate river-floodplain ecosystem: the importance of hydrological extremes. Aquat Ecol 45: 335-349.

Mihaljević M, Žuna Pfeiffer T. 2012. Colonization of periphyton algae in a temperate floodplain lake under a fluctuating spring hydrological regime. Fundam Appl Limnol 180: 13-25.

Mora-Gómez J, Freixa A, Perujo N, Barral-Fraga L. 2016. Limits of the Biofilm Concept and Types of Aquatic Biofilms. In Romani AM, Guasch H, Dolors Balaguer M, eds. Aquatic Biofilms: Ecology, Water Quality and Wastewater Treatment, Caister Academic Press, Norfolk, UK, 3-27.

Moschini-Carlos V, Henry R, Pompêo MLM. 2000. Seasonal variation of biomass and productivity of the periphytic community on artificial substrata in the Jurumirim Reservoir (São Paulo, Brazil). Hydrobiologia 434: 35-40.

Neury-Ormanni J, Vedrenne J, Wagner M, Jan G, Morin S. 2020. Micro-meiofauna morphofunctional traits linked to trophic activity. Hydrobiologia 847: 2725-2736.

Norf H, Arndt H, Weitere M. 2007. Impact of local temperature increase on the early development of biofilm-associated ciliate communities. Oecologia 151: 341-350.

Norf H, Arndt H, Weitere M. 2009a. Effects of resource supplements on mature ciliate biofilms: an empirical test using a new type of flow cell. Biofouling 25: 769-778.

Norf H, Arndt H, Weitere M. 2009b. Responses of biofilm-dwelling ciliate communities to planktonic and benthic resource enrichment. Microb Ecol 57: 687-700.

Norf H, Weitere M. 2010. Resource quantity and seasonal background alter warming effects on communities of biofilm ciliates. FEMS Microbiol Ecol 74: 361-370.

Palijan G, Fuks D. 2006. Alternation of factors affecting bacterioplankton abundance in the Danube River floodplain (Kopački Rit, Croatia). Hydrobiologia 560: 405-415.

Palijan G. 2010. Different impact of flood dynamics on the development of culturable planktonic and biofilm bacteria in floodplain lake. Pol J Ecol 58: 439-448.

Palijan G. 2012. Abundance and biomass responses of microbial food web components to hydrology and environmental gradients within a floodplain of the River Danube. Microb Ecol 64: 39-53.

Parry JD. 2004. Protozoan Grazing of Freshwater Biofilms. In Laskin AI, Bennett JW, Gadd GM, eds. Advances in Applied Microbiology, Vol. 54, Elsevier Academic Press, San Diego, USA, 167-196. 
Peršić V, Čerba D, Bogut I, Horvatić J. 2010. Trophic State and Water Quality in the Danube Floodplain Lake (Kopački Rit Nature Park, Croatia) in Relation to Hydrological Connectivity. In Ansari AA, Singh Gill S, Lanza GR, Rast W, eds. Eutrophication: Causes, Consequences and Control, Springer, Dordrecht, Netherlands, 109-129.

Pratt JR, Cairns J Jr. 1985. Functional groups in the protozoa: roles in differing ecosystems. J Protozool 32: 415-423.

Primc-Habdija B, Habdija I, Plenković-Moraj A. 2001. Tufa deposition and periphyton overgrowth as factors affecting the ciliate community on travertine barriers in different current velocity conditions. Hydrobiologia 457: 87-96.

Primc-Habdija B, Habdija I, Matoničkin R, Špoljar M. 2005. Development of ciliate community on artificial substrates associated with vertical gradients of environmental conditions in a karstic lake. Arch Hydrobiol 164: 513-527.

Risse-Buhl U, Küsel K. 2009. Colonization dynamics of biofilm associated ciliate morphotypes at different flow velocities. Eur $J$ Protistol 45: 64-76.

Rodrigues L, Bicudo DC. 2001. Similarity among periphyton algal communities in a lentic-lotic gradient of the upper Paraná river floodplain, Brazil. Rev bras Bot 24: 235-248.

Safi LSL, Fontoura NF, Severo HJ, Utz LRP. 2014. Temporal structure of the peritrich ciliate assemblage in a large Neotropical lake. Zool Stud 53: 17.

Schwarz U. 2005. Landschaftsökologische Charakterisierung des Kopački Rit unter besonderer Berücksichtigung von Flusslandschaftsformen sowie deren Genese und Typologie. Dissertation am Institut für Geographie, Universität Wien.

Sigee DC. 2005. Freshwater Microbiology: Biodiversity and Dynamic Interactions of Microorganisms in the Aquatic Environment, John Wiley \& Sons, Ltd., West Sussex, England, 544 p.

Sikder MNA, Abdullah Al M, Hu G, Xu H. 2019. Colonization dynamics of periphytic ciliates at different water depths in coastal waters of the Yellow Sea, northern China. J Mar Biol Assoc UK 99: 1065-1073.

Sikder MNA, Xu H, Warren A. 2020. Colonization features of marine biofilm-dwelling protozoa in Chinese coastal waters of the Yellow Sea. Mar Life Sci Technol 2: 292-301.

Stoodley P, Sauer K, Davies DG, Costerton JW. 2002. Biofilms as complex differentiated communities. Annu Rev Microbiol 56: 187-209.

Strickland JDH, Parsons TR. 1968. A practical handbook of sea-water analysis. Bull Fish Res Bord Can 167: 1-310.

Strüder-Kypke M. 1999. Periphyton and sphagnicolous protists of dystrophic bog lakes (Brandenburg, Germany). I. Annual cycles, distribution and comparison to other lakes. Limnologica 29: 393-406.

Strüder-Kypke M, Schönborn W. 1999. Periphyton and sphagnicolous protists of dystrophic bog lakes (Brandenburg, Germany). II. Characteristic species and trophy of the lakes. Limnologica 29: 407-424.

Tadić D, Vidaček Ž. 1999. Klimatske, hidrološke i pedološke značajke. In Mihaljević M, Getz D, Tadić Z, Živanović B, Gucunski D, Topić J, Kalinović I, Mikuška J, eds. Kopački rit Pregled istraživanja i bibliografija, Hrvatska akademija znanosti i umjetnosti, Zagreb, 23-28.

Ter Braak CJF, Šmilauer P. 2002. CANOCO Reference Manual and CanoDraw for Windows User's Guide. Software for Canonical Community Ordination (version 4.5). Microcomputer Power, Ithaca, NY, USA.

Tockner K, Pennetzdorfer D, Reiner N, Schiemer F, Ward JV. 1999. Hydrological connectivity, and the exchange of organic matter and nutrients in a dynamic river-floodplain system (Danube, Austria). Freshw Biol 41: 521-535.

UNESCO, 1966. Determinations of photosynthetic pigments in seawater, Report of SCOR-UNESCO Working Group 17, Monogr Oceanogr Meth, Paris, $69 \mathrm{p}$.

Van der Valk A. 2006. The Biology of Freshwater Wetlands, Oxford University Press, Oxford, UK, 173 p.

Vasudevan R. 2014. Biofilms: microbial cities of scientific significance. J Microbiol Exp 1: 84-98.

Vermaat JE. 2005. Periphyton Dynamics and Influencing Factors. In Azim ME, Verdegem MCJ, van Dam AA, Beveridge MCM, eds. Periphyton: Ecology, Exploitation and Management, $\mathrm{CAB}$ International, CABI Publishing, Wallingford, Oxfordshire, UK, $35-49$.

Verni F, Gualtieri P. 1997. Feeding behaviour in ciliated protists Micron 28: 487-504.

Vidaković J, Bogut I, Borić E, Zahirović Ž. 2002. Hydrobiological research in the Kopački Rit Nature Park in the period November 1997-October 2001. Hrvatske vode/Croat Wat 10: 127-144.

Vidaković J, Palijan G, Čerba D. 2011. Relationship between nematode community and biomass and composition of periphyton developing on artificial substrates in floodplain lake. Pol J Ecol 59: 577-588.

Vidaković J, Turković Čakalić I, Stević F, Čerba D. 2012. The influence of different hydrological conditions on periphytic invertebrate communities in a Danubian floodplain. Fundam Appl Limnol 181: 59-72.

Vidaković J, Turković Čakalić I, Vlaičević B, Galir Balkić A, Turić N. 2017. Biodiversity of aquatic invertebrates in association with natural substrates in a floodplain lake (the Kopački Rit Nature Park, Croatia). In Ozimec S, Bogut I, Rožac V, Stević F, Bolšec B, Baković A, eds. Book of abstracts of the 6th symposium Kopački Rit: Past, Present, Future 2017, Public Institution Kopački Rit Nature Park, Tikveš, 103-104.

Villanueva VD, Schwartz FJT, Romani AM. 2011. Biofilm formation at warming temperature: acceleration of microbial colonization and microbial interactive effects. Biofouling 27: 59-71.

Vlaičević B, Vidaković J, Čerba D. 2017. The colonization and succession patterns of the periphytic ciliate community in a temperate floodplain lake. Biologia 72: 305-318.

Weitere M, Schmidt-Denter K, Arndt H. 2003. Laboratory experiments on the impact of biofilms on the plankton of a large river. Freshw Biol 48: 1983-1992.

Weitere M, Erken M, Majdi N, Arndt H, Norf H, Reinshagen M, et al. 2018. The food web perspective on aquatic biofilms. Ecol Monogr 88: $543-559$

Wetzel RG. 2001. Limnology. Lake and River Ecosystems, third ed, Academic Press, San Diego, 1006 p.

Wetzel RG. 2005. Periphyton in the Aquatic Ecosystem and Food Webs. In Azim ME, Verdegem MCJ, van Dam AA, Beveridge MCM, eds. Periphyton: Ecology, Exploitation and Management, CAB International, CABI Publishing, Wallingford, Oxfordshire, UK, 51-69.

Wey JK, Jürgens K, Weitere M. 2012. Seasonal and successional influences on bacterial community composition exceed that of protozoan grazing in river biofilms. Appl Environ Microbiol 78: 2013-2024.

Wey JK, Norf H, Arndt H, Weitere M. 2009. Role of dispersal in shaping communities of ciliates and heterotrophic flagellates within riverine biofilms. Limnol Oceanogr 54: 1615-1626.

Wu Y. 2017. Periphyton: Functions and Application in Environmental Remediation. Elsevier Inc. Amsterdam, Boston, Heidelberg, 
B. Vlaičević et al.: Knowl. Manag. Aquat. Ecosyst. 2021, 422, 33

London, New York, Oxford, Paris, San Diego, San Francisco, Singapore, Sydney, Tokio, $434 \mathrm{p}$.

Yang Z, Xu Y, Xu G, Xu H. 2016. Carbon flux of trophic-functional groups within the colonization process of biofilm-dwelling ciliates in marine ecosystems. J Mar Biol Assoc UK 96: 1313-1318.

Zhang W, Xu H, Jiang Y, Zhu M, Al-Rasheid KAS. 2012. Colonization dynamics in trophic-functional structure of periphytic protist communities in coastal waters. Mar Biol 159: 735-748.

Zhang W, Xu H, Jiang Y, Zhu M, Al-Rasheid KAS. 2013. Colonization dynamics of periphytic ciliate communities on an artificial substratum in coastal waters of the Yellow Sea, northern China. J Mar Biol Assoc UK 93: 57-68.

Žuna Pfeiffer T, Mihaljević M, Stević F, Špoljarić D. 2013. Periphytic algae colonization driven by variable environmental components in a temperate floodplain lake. Ann Limnol - Int J Lim 49: $179-190$.

Žuna Pfeiffer T, Mihaljević M, Špoljarić D, Stević F, PlenkovićMoraj A. 2015. The disturbance-driven changes of periphytic algal communities in a Danubian floodplain lake. Knowl Manag Aquat Ecosyst 416: 02 .

Cite this article as: Vlaičević B, Matoničkin Kepčija R, Gulin V, Turković Čakalić I, Kepec M, Čerba D. 2021. Key drivers influencing the colonization of periphytic ciliates and their functional role in hydrologically dynamic floodplain lake ecosystem. Knowl. Manag. Aquat. Ecosyst., 422, 33. 